Universidade de Brasília

Instituto de Letras

Departamento de Teoria Literária e Literaturas

Programa de Pós-Graduação em Literatura

NARRATIVAS DA VIOLÊNCIA: ESTRELLA DISTANTE, AMULETO E NOCTURNO DE CHILE DE ROBERTO BOLAÑO

Clara Bomfim dos Santos

Orientador: Paulo César Thomaz

Brasília - DF

2015 
Clara Bomfim dos Santos

NARRATIVAS DA VIOLÊNCIA: ESTRELLA DISTANTE, AMULETO E NOCTURNO DE CHILE DE ROBERTO BOLAÑO

\begin{abstract}
Dissertação apresentada ao Programa de Pós-Graduação em Literatura do Departamento de Teoria Literária e Literaturas - TEL do Instituto de Letras da Universidade de Brasília - UnB como requisito parcial para a obtenção do título de Mestre.
\end{abstract}

Área de concentração: Literatura

Linha de Pesquisa: Representação na literatura contemporânea

Orientador: Prof. Dr. Paulo César Thomaz

Brasília - DF

2015 
Clara Bomfim dos Santos

\section{NARRATIVAS DA VIOLÊNCIA: ESTRELLA DISTANTE, AMULETO E NOCTURNO DE CHILE DE ROBERTO BOLAÑO}

Banca Examinadora

Maria Isabel Edom Pires

(Presidente da Banca)

Igor Ximenes Graciano

(Membro externo)

José Luís Martínez Amaro

(Membro interno)

Erivelto da Rocha Carvalho

(Membro suplente) 
A todos aqueles que perderam uma parte de si, fosse ela em outro alguém, vítimas da violência na América latina. 


\section{Agradecimentos}

Em primeiro lugar, ao meu orientador, Paulo Thomaz, por enxergar uma capacidade talvez adormecida e despertá-la para o rumo que me fez chegar até aqui. Pelo companheirismo e paciência além do comum.

À minha mãe por desde sempre me mostrar, pela dura ótica da realidade, que a educação é o único caminho. Ao meu irmão, pelas discussões frutíferas.

Ao meu esposo Leonardo, por me acompanhar nessa jornada da maneira mais compreensiva possível. Aos meus filhos Nicolas e Átila, por existirem, por serem meu apoio incondicional.

Às minhas amigas-irmãs Giu, Édelyn e Elisa, pelos ombros mais que amigos. À Ludimila, aquela garota que é maior que as outras.

À Ísis, Rainer e Ana Helena, pela parceria além da graduação, filhos que adotei para a vida. À Luciana Teixeira e Camila Godinho, parceiras de orientação e tensão. À Cida Cruz, Dalva Martins e Elizabete Barros, parceiras da vida acadêmica e do rock.

Ao Grupo de Estudos em Literatura Brasileira Contemporânea (GELBC), pela acolhida. Aos professores José Luís Martínez, Anderson da Mata e Maria Isabel Edom, por serem inspiração. 
De la violencia, de la verdadera violencia, no se puede escapar, al menos no nosotros, los nacidos en Latinoamérica en la década de los cincuenta, los que rondábamos los veinte años cuando murió Salvador Allende.

Putas asesinas

Roberto Bolaño 


\section{RESUMO}

O objetivo dessa dissertação foi analisar o modo como a narrativa ficcional do escritor chileno Roberto Bolaño atravessa questões de ordem política, relacionadas aos períodos ditatoriais na América Latina, destacando o papel da violência como meio mantenedor de poder, numa tentativa de mostrar a permanência dessas questões na contemporaneidade. Para isso, analisamos a maneira como Bolaño ficcionaliza os mecanismos de poder em três romances específicos: Estrella distante, Amuleto e Nocturno de Chile. Nossa intenção foi explorar a representação da violência nesses romances, a fim de estabelecer ligações entre política e cultura, literatura e sociedade, violência e poder, concebidas de maneira única na estética narrativa deste autor.

Palavras-chave: Roberto Bolaño, literatura, política, violência, estética. 


\section{ABSTRACT}

This dissertation's purpose was to analyze how the fictional narrative of the Chilean writer Roberto Bolaño crosses political issues, related to periods of dictatorship in Latin America, highlighting the role of violence as a mean maintainer of power, in attempt to show the permanence of these issues nowadays. For this, we analyze how Bolaño fictionalizes the mechanisms of power in three specific novels: Estrella distante, Amuleto and Nocturno de Chile. Our intention was exploring the portrayal of violence in these novels, in order to establish links between politics and culture, literature and society, violence and power, designed in a uniquely aesthetic way in this author's narrative.

Key-words: Roberto Bolaño, literature, politics, violence, aesthetic. 


\section{RESUMEN}

El objetivo de esta disertación fue analizar el modo cómo la narrativa ficcional del escritor chileno Roberto Bolaño atraviesa cuestiones de orden político, relacionadas a los períodos dictatoriales en Latinoamérica, destacando el rol de la violencia como medio de manutención del poder, en un intento de mostrar la permanencia de estas cuestiones en la contemporaneidad. Para tanto, analizamos la manera como Bolaño ficcionaliza los mecanismos de poder en tres novelas específicas: Estrella distante, Amuleto y Nocturno de Chile. Nuestra intención fue explorar la representación de la violencia en estas novelas, a fines de establecer vínculos entre política y cultura, literatura y sociedad, violencia y poder, planteadas de manera única en la estética narrativa de este autor.

Palabras-clave: Roberto Bolaño, literatura, política, violencia, estética. 


\section{Sumário}

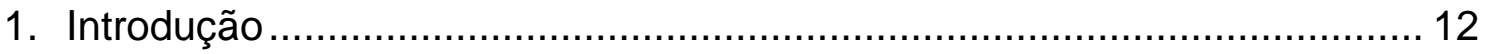

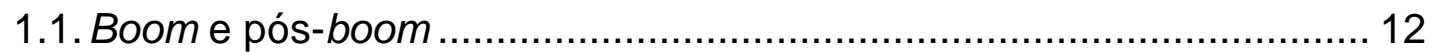

1.2. Passagem para a democracia ..................................................... 14

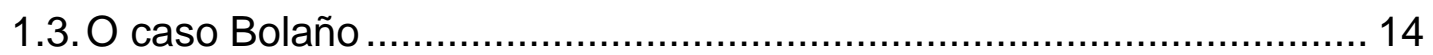

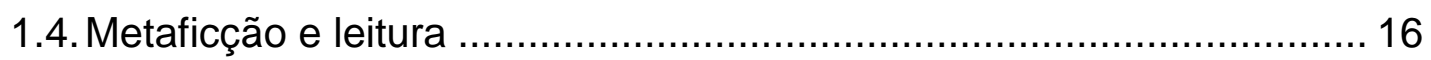

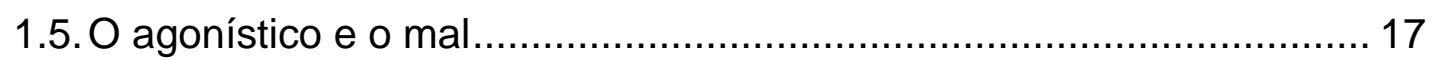

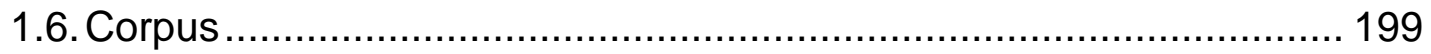

2. Biopolíticas: a lógica da depuração em Estrella distante ............................ 23

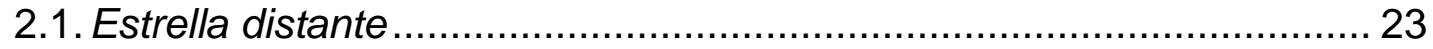

2.2. Biopolíticas e a banalização da violência ........................................... 28

2.1.1. Descartabilidade da vida ................................................ 30

2.2.2. Foucault, Bolaño e o poder .............................................. 31

2.2.3. Depuração e monstros ..................................................... 34

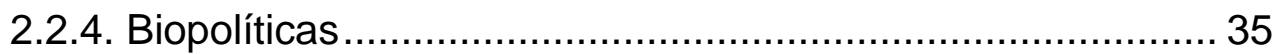

2.3. O Estado de exceção como regra na contemporaneidade.................... 38

2.3.1. Narrativas do Homo sacer................................................. 41

2.4. Vanguardismos e a lógica da depuração ............................................. 42

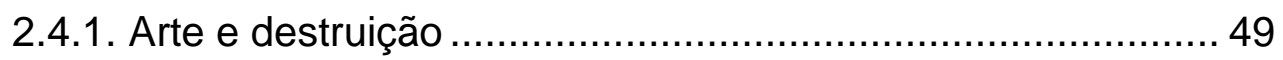

2.5. Tanatopolítica, violência e arte ...................................................... 51

3. Poesia e (resistência à) violência em Amuleto........................................... 56

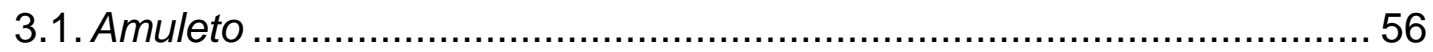

3.2. A voz de Auxilio: relato marginal .................................................... 57

3.2.1. Colonialismo e pensamento liminar ................................... 58

3.3. Narrativas do trauma: testemunho e irrepresentabilidade ..................... 61

3.4. Amuleto: o canto de uma geração ..................................................... 63

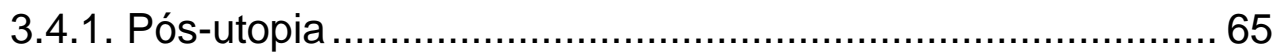


4. Violência, Chile e exílio em Estrella distante e Nocturno de Chile 67

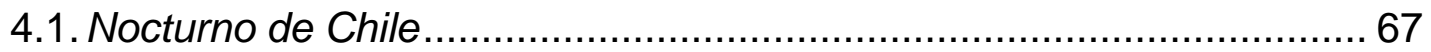

4.2. América Latina e Bolaño: marcas de um exílio permanente................. 69

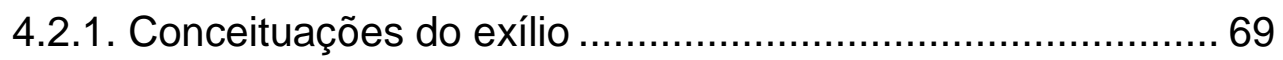

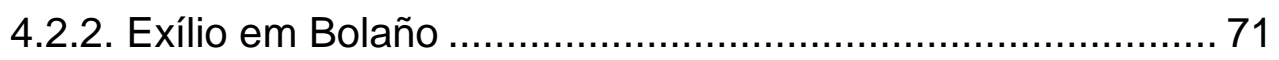

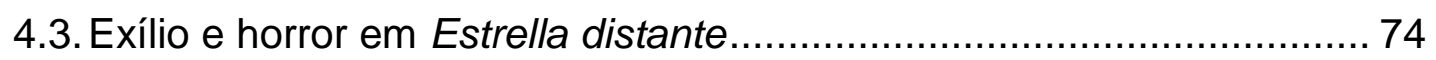

4.4. Exílio em Nocturno de Chile: nova perspectiva ................................. 77

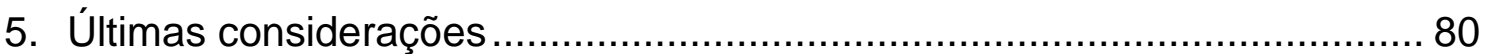

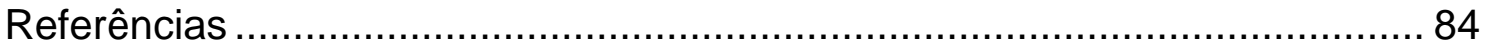




\section{Introdução}

Todos sus personajes son escritores. Sin embargo, el tema de Bolaño no es tanto la literatura como las oscuras relaciones entre el arte y la barbarie, en el marco de la historia latinoamericana. (GONZALO AGUILAR, 2001)

\subsection{Boom e pós-boom}

A literatura latino-americana alcançou reconhecimento internacional a partir dos anos sessenta do século XX. Esse momento, conhecido como o boom da literatura latino-americana, esteve intimamente ligado à expansão do mercado editorial no continente e à nova inscrição do intelectual nas demandas literárias da sociedade, frutos da realidade social do período (RAMA, 1982). A essa etapa se seguiram novas discussões, surgidas já no fim dessa década, que caracterizariam outro período, denominado pós-boom por alguns críticos (SHAW, 1998).

O que há de significativo nessas caracterizações é que tanto o boom quanto o pós-boom são termos que se referem especificamente a um âmbito, a narrativa literária, e a uma região particular, a América Latina, diferentemente do que ocorre com o pós-modernismo, por exemplo, que intenciona fazer referência a uma totalidade tanto geográfica quanto artística. Em contraponto à relativa uniformidade e do número relativamente pequeno de obras do boom, o pós-boom constitui um fenômeno de maior amplitude e também de maior diversidade literária; além disso, parece que o pós-boom nunca esteve em busca de um romance total, ao contrário do que foi tentado durante o boom.

Nessa perspectiva, desde inícios da década de 1970, começa a perfilarse como constante temática do pós-boom o afã de preservar, fomentar ou recuperar a/s identidade/s latino-americana/s, seja em ordem continental, nacional, regional ou local; em obras mais recentes, publicadas a partir dos anos 90, alguns escritores, entre os quais Roberto Bolaño, parecem inclusive querer destruir esse essencialismo identitário presente na ficção latino- 
americana. O trágico impacto causado pelos regimes totalitários no continente, assim como a experiência do exílio e do desarraigamento, parece haver determinado em grande parte dos escritores do pós-boom uma inclinação para um tipo de literatura na qual se expressam de maneira explícita tais experiências, e na qual abundam a denúncia social, ideológica e política. Isso não significa que os romances do boom não tenham abordado tais tópicos relacionados à América latina; o que distinguiria a narrativa do pós-boom é um tratamento mais direto e mais simples da realidade política e sociocultural latino-americana, enquanto nos romances do boom o latino-americano costumava perder o protagonismo ou ficar submetido a uma busca pelo cosmopolitismo ou universalidade.

O pós-boom molda uma literatura predominantemente urbana, e nela incorpora numerosos elementos da cultura juvenil, o funculture, como as drogas, o sexo, a marginalidade, distintas expressões da cultura popular (cinema, moda, esportes, televisão, gêneros musicais). Nos romances do pósboom esses elementos não constituem meras referências ao extratexto, mas são manifestações culturais assumidas plenamente pelas personagens, que formam parte integrante de suas vidas, determinando em grande medida suas respectivas condutas, sentimentos e pontos de vista (IDEM).

Na era do pós-boom, a atenção da crítica e do público leitor já não está dirigida unicamente a uns poucos grandes romancistas (autores de obras igualmente monumentais), mas abarca um número muito maior de autores que praticam ou dão origem a diversas e numerosas tendências literárias. Surgem assim novos gêneros marginais destacados pela crítica: realismo crítico urbano, regionalismo cultural judeu, retorno à história, narrativa de testemunho, literatura latina (narrativa escrita em espanhol, inglês ou spanglish nos EUA), romance de temática homossexual, literatura afro-hispânica, entre outros, o que explicita a diversidade temática característica do pós-boom (IDEM).

Uma das temáticas que surge dessa marginalidade, aliada ao momento histórico pós-ditatorial, trata da violência, tema que não é exclusivo do "pósboom". Há uma longa tradição literária latino-americana que trata da violência; inclusive há um gênero que trata apenas dos romances de ditadores. Que a 
América Latina é o continente violento por excelência parece opinião comum, embora alguns acontecimentos recentes e não tão recentes ocorridos em diversos países possam indicar que nós latino-americanos não nos encontremos isolados nesse sentido.

\subsection{Passagem para a democracia}

A última década do século $\mathrm{XX}$, durante a qual se completou a transição democrática em uma série de países que haviam sofrido ditaduras militares, não conseguiu apagar as dolorosas recordações que permanecem na superfície, como quando algum ou outro oficial argentino culpado de torturas é desmascarado e condenado ou, no caso do Brasil, com as revelações feitas à recém-criada Comissão da Verdade.

Em um sentido mais amplo, ainda no século $X X I$, as estatísticas permanecem em desfavor no que diz respeito à questão da violência. As revoltas em Chiapas, a ação da guerrilha e da máfia na Colômbia, os excessos da polícia, os altos índices de criminalidade e outros tantos fenômenos colaboram em manter viva a fama de violento da qual sofre o "subcontinente" latino-americano. Não é de surpreender, portanto, que a violência na América Latina continue a ter a sua contrapartida nos textos literários, como afirma Ariel Dorfman:

Decir que la violencia es el problema fundamental de América y del mundo es sólo constatar un hecho. Que la novela hispanoamericana refleja esa preocupación se advierte en cada página escrita en nuestro continente, esas páginas que son como la piel de nuestros pueblos, los testigos de una condición siempre presente. (DORFMAN, 1972, p. 9)

\section{3. $O$ caso Bolaño}

Nesse contexto de violência e literatura, encontramos inserida a obra narrativa do escritor chileno Roberto Bolaño. Sua produção surge como um dos mais destacados êxitos editoriais desde o chamado boom latino-americano, 
principalmente a partir de 1998, quando um de seus mais famosos romances, Los detectives salvajes, recebe em Caracas o prêmio internacional de romance Rómulo Gallegos. A produção literária de Bolaño, que compreende diversos gêneros, não deve, no entanto, ser entendida como mero modismo literário: tratam-se de narrativas profundamente ligadas à história do Chile e da América Latina, que a todo momento tocam em questões políticas, combinadas com uma poética e um projeto estético que tem fascinado o público leitor no mundo inteiro.

A figura de Roberto Bolaño é determinante para os ares de renovação que acompanham os escritores latino-americanos do século XXI. A publicação em inglês de 2666 iniciou o chamado caso Bolaño e irrompeu no panorama crítico estadunidense, canonizando abruptamente o autor e o conjunto de sua obra. A partir desse momento, se reinventa a figura do escritor, frequentemente falseando-a e apresentando-a em numerosas ocasiões como "uno de esos escritores furiosos, destacados y menospreciados por sus contemporáneos y que, sólo a través de una férrea lucha individual, logran convertirse en artistas trágicos, en héroes póstumos" (VOLPI, 2009, p. 74). De tal forma que com Bolaño tentaram recuperar a aura do escritor maldito, ainda que, por outro lado, esse fato tenha contribuído para seu êxito póstumo. Todavia, Jorge Volpi assinala que ainda que Bolaño seja admirado pelas novas gerações de escritores, estes não têm seguido a relação especial que o escritor mantinha com a tradição, dentro da qual também implicou uma ruptura, visto que:

[...] sus textos pertenecen en cambio a otra era y se construyen de forma semejante a los vínculos de la red: obras dispersas, de tamaño, composición y estilos variables, que se hallan interconectadas entre sí, y cuyas historias saltan de un formato a otro. Si uno hace clic en cierto lugar de La literatura nazi en América (1996) llega a Estrella distante (1996), o, a la inversa, un pasaje de Los detectives salvajes conduce a Amuleto (1999), por no hablar de las infinitas conexiones abiertas en 2666. (IBIDEM, p. 177)

De fato, as obras de Bolaño, ao mesmo tempo em que parecem render homenagens ao boom, também destacam uma reinventada fé latinoamericanista. A partir dos anos 80 , quando o movimento se transforma em um paradigma obsoleto, porém ainda imperante, Bolaño se propõe a subvertê-lo 
desde dentro: daí o paradoxo de que seus livros estejam "llenos de parodias y burlas, de juegos estilístico, de socarronería y mala leche y, sottovoce, de honda admiración" (VOLPI, 2011, p. 1). Se a narrativa de Bolaño está tão presente nos escritores atuais é porque seu signo literário está marcado pelo retrato do mal, do horror e da violência na construção de todo um imaginário apocalíptico, como mostram os romances que escolhemos como corpus de pesquisa, Estrella distante, Amuleto e Nocturno de Chile.

No entanto, apesar de que nesses romances o tratamento do mal se reduza ao âmbito latino-americano, em outras obras posteriores Bolaño parece deslocar esta problemática a um contexto universal, à caminhada do homem ao longo do século XX, como vemos por exemplo no romance 2666, ambientado em cenários como os Estados Unidos e a Europa, além da própria América Latina.

\subsection{Metaficção e leitura}

A figura do escritor possui extrema relevância no universo bolaniano; ele sempre o perfila em suas narrativas como alguém que luta contra as injustiças do mundo, sempre pairando no limiar do abismo, um escritor em ação para que a arte apareça sempre ligada à violência e à morte e que por isso sempre está condenado à derrota, porém nunca por isso deixando de tentar. Por esse motivo, apreciamos em sua obra literária um duplo paradigma do escritor, aquele que se constitui em modelo, que enfrenta o poder estabelecido e sai vitorioso, que parece formar parte da indústria cultural, porém sempre tratando de sabotá-la desde dentro. Nos três romances que analisaremos nessa pesquisa, temos o exemplo do anti-modelo, do escritor que se escraviza diante de dita indústria e acaba caindo nas redes do poder.

Poderíamos sugerir aqui que Bolaño inventa seu próprio século. As leituras e influências dele são muito variadas: Bolaño era um leitor enciclopédico e eclético que lia Pascal, Wittgenstein, ao lado de Dick, Ellroy e Fresán. Da ficção científica à literatura policial, passando por filmes considerados B; de Poe a Carver, passando por Borges, Cortázar e Perec, sem 
deixar de lado a poesia, em especial os franceses do século XIX e os poetas chilenos Nicanor Parra e Enrique Lihn, conforme constatamos em visita à exposição de seu arquivo pessoal em Barcelona, cidade onde viveu seus últimos anos (CCBB, 2013).

A partir de tantas influências, Bolaño traça sua obra lançando mão de uma estética fragmentária, se instalando claramente em uma extrema contemporaneidade, conforme vemos em Maurice Blanchot em seu La escritura del desastre:

La escritura fragmentaria sería el riesgo mismo. No remite a una teoría, no da cabida a una práctica definida por la interrupción. Interrumpida, prosigue. Ante un interrogante, no se arroga la pregunta sino que la suspende (sin mantenerla) en no respuesta. (BLANCHOT, 1992, p. 56)

Bolaño sabe que, para significar o que quer significar sobre o contexto histórico/político/social no qual se encontra, a escrita fragmentária é a única alternativa. A literatura é a escrita do desastre. Ainda em Blanchot:

[...] cuando Kafka le da a entender a un amigo que él escribe porque, de otra manera, se volvería loco, sabe que escribir ya es una locura, su locura, una especie de vigilia fuera de conciencia, insomnio. Locura contra locura: cree que domina la primera entregándosele; la otra le da miedo, es su miedo, le traspasa, le desgarra, le exalta, como si tuviera que sufrir la omnipotencia de una continuidad sin tregua, tensión al límite de lo soportable. Habla de ello con espanto pero también con sentimiento de gloria, pues la gloria es el desastre. (IBIDEM, p. 43)

\subsection{O agonístico e o mal}

Bolaño assume o risco da literatura como desastre. Assim, aqui sugerimos que o chileno decide recorrer ao aspecto "agonístico" do século passado para nortear sua escrita; por essa razão, identificamos como traço característico de sua obra a representação do mal da história, do horror extremo, da violência peculiar do século XX. Ao confrontar as duas supostas alternativas propostas pelas teorias do início do século - a nacionalização da 
política ou a politização da estética, presentes no nó da origem do conceito de totalitarismo, tão arraigado entre outras coisas, como a noção atual de terrorismo de direitos humanos (BENJAMIN, 1994) -, Bolaño opta por escrever assumindo uma tensão incessante entre política e estética.

E é essa tensão que assumimos como ponto de partida de análise do nosso corpus. O mal da história na escrita de Bolaño é um raio potente que agride as histórias e personagens e o próprio contexto narrativo, criando uma voz uníssona, um vínculo entre linguagem e significado, caracterizados pela língua do mal.

Em alguns romances, como Estrella distante, Amuleto e Nocturno de Chile, estruturam-se os rompantes históricos mais aterradores, as partículas implosivas que germinam como uma aberração sobre a convivência, o pathos que destrói e fica como impressão histórica marcada. Há uma patologia do escárnio social e da deformação das estruturas coletivas. Esse olhar do autor se estende desde a decisão de representar a história a partir do absurdo e da subversão até desabilitar, ou contrapor e desdenhar, figuras e acontecimentos históricos. Não se trata nem de construir um paralelo entre o fato histórico e o literário, mas sim de dinamitar a história a partir dessa linguagem do mal até fazê-la irreconhecível.

Neste trabalho, nossa intenção é analisar o modo como o mal e a violência estão representados na ficção bolaniana. Ana Maria Amar Sánchez, ao analisar textos literários de grandes autores latino americanos, assinala:

Puede concluirse que la representación, entendida como una construcción discursiva, produce - y no reproduce - una lectura sobre lo dado. Por lo tanto, las representaciones de los textos en el corpus elegido no reflejan ni reproducen una imagen de Latinoamérica más o menos cercana a lo real (...). Configuran un imaginario sobre ella y dramatizan la tensión y las contradicciones presentes en una multiplicidad de discursos, no sólo literarios, con los que se pensó y se piensa América Latina. (SANCHEZ, 1996. p. 3) 


\title{
1.6. Corpus
}

Começamos a análise de nosso corpus com Estrella distante, publicada em 1996. Extensão e aprofundamento do último capítulo de La literatura nazi en América (Ramírez Hoffman, el infame), esse romance retrata o mal em seu estado mais puro, que parece personificar-se em Carlos Wieder, poeta aéreo e assassino que agiu durante o regime militar chileno. A partir de aproximações infrutíferas e muitas vezes baseadas em conjecturas, o narrador do texto, Arturo B., reconstrói a vida e os crimes desse homem, alçado ao grau de lenda, que une em si mesmo a arte e o horror.

Nesse sentido, em análise do romance, Celina Manzoni põe o foco, por exemplo, sobre a proposta de Bolaño com relação ao uso da linguagem e tratamento da história:

\begin{abstract}
Si la pérdida de tradiciones democráticas que parecían tan rotundamente afirmadas en Chile ha fragmentado la Historia, y con ella los lenguajes, la literatura de Bolaño parece proponerse como una respuesta al fracaso de los intentos de construcción de una narrativa a partir de un único punto de vista que además busca perpetuarse en una retórica que formula una política de transacción del olvido. Una voluntad estética orientada a capturar el despliegue de las diferencias, le permite a su vez diferenciarse de la seguridad y también de la banalidad y el adelgazamiento de los intentos de representación mimética, así como abandonar la ilusoria y antigua eficacia colocada en las verdades dichas con estridencia, para adoptar en su lugar los lenguajes de la reflexión, no sólo estética sino también ética y política. (MANZONI, 2006, p. 42)
\end{abstract}

$\mathrm{Na}$ tentativa de esboçar as relações entre política e literatura nesse romance, partimos da chave da representação da violência na obra para traçar uma análise de um conceito que acreditamos permear toda a bibliografia de Bolaño: a biopolítica. A partir da criação desse conceito, que aparece pela primeira vez nos estudos do filósofo francês Michel Foucault, analisaremos no capítulo 1 o caminho que a biopolítica percorre no fim do século $X X$ e início do século XXI, indo ao encontro de estudos sociológicos sobre a banalização do 
mal e os vínculos que alguns autores assinalam sobre a continuidade do Estado de exceção no período pós-ditatorial na América Latina.

É também nesse capítulo que faremos referência a um conceito criado pelo filósofo francês Alain Badiou para falar das especificidades do século XX e que entendemos como outro elemento importante para a compreensão da obra de Bolaño enquanto representação do mal: a lógica da depuração, ou o caráter depurador da violência de Estado na contemporaneidade. A lógica da morte surge aqui como ponto crucial dessa análise, o que nos faz seguir por um caminho que nos leva a uma nova política surgida da união entre biopolítica e depuração, a tanatopolítica.

No capítulo 2, analisaremos Amuleto, publicado em 1999. Também emanado de um episódio de outro romance do autor, nesse caso Los detectives salvajes - que por sua vez resgata La noche de Tlatelolco, de Elena Poniatowska -, este romance é narrado por uma uruguaia que permaneceu presa em um banheiro da Faculdade de Filosofia e Letras durante a invasão dos militares à Universidade Autônoma do México (UNAM). Nesse ínterim, Auxilio Lacouture recorda sua chegada ao México e faz constantes movimentações temporais, marcadas pelo deslocamento da lua que percebia através das janelas, onde mescla indistintamente realidade e ficção e onde reaparece também a figura de Arturo Belano (ou Arturo B. como em Estrella distante).

Nossa tentativa neste capítulo foi realizar uma leitura de como Bolaño se esforça nesse romance para apresentar um discurso sobre o poder, a memória e a história na América Latina, tendo como ponto de vista e estratégia discursiva a mirada marginalizada e alucinada de sua narradora. Aqui também abordaremos os conceitos de testemunho e irrepresentabilidade do horror, pontos sempre explorados quando se tratam de questões literárias e estéticas relacionadas ao período histórico subsequente às ditaduras latino-americanas.

É com a análise de Amuleto que percebemos em Bolaño um anseio de conectar poesia e resistência, item que funcionará nesse capítulo como eixo da ligação que faremos entre violência e literatura, conforme descrito por Rodrigo Ramírez Morales: 
En un momento, la voz de Auxilio menciona: "Porque escribí, resistí". Esta cita podría enmarcar toda una línea de escritura que se genera en el continente: la escritura como resistencia. Qué es la escritura sino la mejor forma de resistir, y en esa labor la mejor forma de no olvidar. En la letra queda grabado todo testimonio. (MORALES, 2007, p. 14)

No terceiro e último capítulo, apresentaremos nossa pesquisa sobre o romance Nocturno de Chile, publicado em 2000, uma das obras mais polêmicas de Bolaño, muito por conta da clara correspondência existente entre suas personagens e personagens reais que protagonizaram feitos reconhecíveis e reprováveis durante a ditadura chilena.

Durante aquela que acredita ser a última noite de sua vida, o sacerdote da Opus Dei e crítico literário Sebastián Urrutia Lacroix reconta seus anos e suas obras, a fim de exorcizar seus demônios e justificar seus erros. O romance apresenta o extenso parágrafo deste reconto, onde realidade e ficção se misturam tanto no relato febril do sacerdote como na contaminação dos marcos referenciais internos e externos, como na alusão que Lacroix faz ao religioso Ignacio Valente, crítico literário do jornal chileno "El Mercurio". A personagem María Canales, anfitriã e patrocinadora de escritores, tem clara inspiração em Mariana Callejas, mulher do torturador Michael Townley, entre outros exemplos.

O que nos chama a atenção para esse romance específico e o diferencia dos outros presentes em nosso corpus é o lugar de fala do narrador: em Nocturno de Chile ele não é um Arturo Belano ou uma Auxilio Lacouture, poetas à margem da sociedade. Trata-se de um representante de uma classe social mais favorecida. Para Soldán, "Nocturno de Chile es la confesión del civilizado que con su silencio es cómplice del horror. Nocturno de Chile es la novela de la complicidad de la literatura, de la cultura letrada, con el horror latinoamericano" (SOLDÁN, 2009, pp. 219-220).

A estética diferenciada da narrativa nos levou neste capítulo a analisar a relação entre violência e literatura a partir de uma outra chave histórica, porém muito caraterística dos períodos pós-ditatoriais latino-americanos: o exílio. Para isso, nossa análise conta com o romance Estrella distante, que analisamos no 
primeiro capítulo, posto que seu narrador também narra sua história a partir do exílio.

Apesar de ter abandonado o Chile ainda muito jovem e de ter residido em outros países ao longo de sua vida, Bolaño parece nunca ter perdido o interesse de recuperar suas raízes chilenas, como nos mostram esses dois romances específicos, assim como em Estrella distante também parece estabelecer um diálogo sem fetichismos com sua própria origem através da personagem de Arturo Belano, uma espécie de alter-ego literário. Nossa tentativa neste terceiro e último capítulo é encontrar nestes romances sinais que evidenciem as relações entre Bolaño e o Chile, ou melhor, entre suas personagens e a questão do exílio relacionado à violência, considerando que tratam-se de vínculos não essencialistas, uma vez que Bolaño aparentava certo horror aos nacionalismos e ao fetichismo identitário. 


\section{Biopolíticas: a lógica da depuração em Estrella distante}

Los que tienen el poder (aunque sea por poco tiempo) no saben nada de literatura, sólo les interesa el poder. Y yo puedo ser el payaso de mis lectores, si me da la real gana, pero nunca de los poderosos. Suena un poco melodramático. Suena a declaración de puta honrada. Pero, en fin, así es.

(Roberto Bolaño, Entre paréntesis).

\subsection{Estrella distante}

O romance Estrella distante, do escritor chileno Roberto Bolaño, lançado em 1996, é o que se chama de spin-off, termo em inglês usado como sinônimo de derivação; nesse caso, um romance derivado de outro, ou melhor, das últimas vinte páginas do curioso porta-retratos de escritores latino-americanos fictícios desenhado por Bolaño em La literatura nazi en América, livro no qual o escritor traça relações entre a literatura supostamente produzida na América e o regime nazifascista.

La literatura nazi en América foi o primeiro romance que deu visibilidade à obra de Bolaño. Pode ser visto como um universo no qual nos é revelada uma comunidade de infames, unidos por certa atmosfera familiar, em virtude das diferentes filiações de suas vidas e obras a certa ideia ou ideologia do nazismo. Esta obra é frequentemente associada à História geral da infâmia de Borges, sendo entendida como uma espécie de homenagem de Bolaño ao escritor argentino.

No capítulo deste livro dedicado ao personagem chamado Ramírez Hoffman, Bolaño traça um perfil e narra as controversas peripécias deste poeta e assassino, que ousadamente desenhava poemas com fumaça de aviões nos céus chilenos. O conteúdo de Estrella distante é um aprofundamento do perfil do poeta, chamado inicialmente de Alberto Ruiz-Tagle (e depois Carlos Wieder), narrado pela visão de um companheiro dos tempos de oficinas literárias universitárias. 
A relação entre as duas histórias é citada por Celina Manzoni no primeiro capítulo do livro organizado por ela, Roberto Bolaño: la escritura como tauromaquía, onde afirma:

[...] la historia de este personaje (Ramírez Hoffman), uno de los tres chilenos que integran el catálogo de La literatura nazi en América, que resucita bajo otros nombres y falsos nombres es re-contada como espejo y explosión de sí misma en Estrella distante. (MANZONI, 2006, p. 21)

Reconhecemos em Estrella distante o narrador, Arturo Belano. Essa personagem, que aparece aqui pela primeira vez e depois se faz presente em várias obras de Bolaño, tem sua trajetória confundida com a do próprio autor, o que lhe confere um efeito autobiográfico. O próprio Bolaño chegou a afirmar em entrevistas que Belano representava "o que ele queria ter sido, ou melhor, o que ele se salvou de ser". Belano é um jovem poeta chileno, que transita entre oficinas de literatura do Chile de Allende, onde circulam outros jovens poetas como ele, ou seja, o futuro da poesia chilena. Entre eles, o misterioso e, na visão do narrador, não muito talentoso Alberto Ruiz-Tagle. Após o golpe militar, na prisão, o narrador testemunha a manifestação poética aérea de um tenente chamado Carlos Wieder, identificado depois como sendo o próprio Ruiz-Tagle, poeta e também assassino.

Esta personagem concentra o mistério e o suspense estrutural do romance (principalmente o da busca do detetive Romero pelo paradeiro de Wieder, após seu desaparecimento do Chile), o que dá ao texto uma característica policialesca, uma das inúmeras possibilidades de classificação desta obra de Bolaño, e enfatiza o caráter ficcional da mesma, pois se estrutura por meio de vários gêneros literários, sejam eles cultos ou populares.

No prólogo do livro de Manzoni, encontramos uma tentativa crítica de traçar as linhas gerais da obra do escritor chileno que identifica essa mistura:

Su proyecto de escritura, sustentado en la pasión de contar, propone una poética en la que confluyen y se cruzan con libertad formas culturales que, de manera tradicional, han sido catalogadas y discriminadas por su condición, de 'cultas' o de 'populares'. (IBIDEM, p.13-14) 
A obra de Bolaño não está sozinha no contexto da hibridização de gêneros. Sua geração tentou ser um novo movimento de escritores hispanoamericanos decididos a romper com a marca deixada pelo boom literário da década de 60. Escritores como o argentino Manuel Puig incorporaram formalmente às suas obras técnicas narrativas próprias de outros suportes artísticos, como o cinema, e introduziram temas relativos à cultura popular. A eles se seguiram vários outros, como o mexicano Juan Villoro, o espanhol Enrique Vila-Matas e o próprio Bolaño. Esses escritores deram início ao processo de revalorização de distintos gêneros considerados menores, como a ficção científica, a crônica de viagem, o terror, o romance de detetive e 0 thriller, entre outros.

O desenho ficcional de Estrella distante foi construído a partir de episódios significativos do contexto histórico das décadas de 1970/1980. Os fatos relatados no livro fazem referência à época do regime militar chileno, tanto aos anos prévios como aos posteriores a este período iniciado em 1973. O texto é claro no intuito de datar o contexto histórico; desde as primeiras linhas, essa informação é expressamente anunciada: "La primera vez que vi a Carlos Wieder fue en 1971 o tal vez em 1972, cuando Salvador Allende era presidente de Chile" (BOLAÑO, 1996, p. 13).

Em uma época em que o Estado de direito e as tradições republicanas foram totalmente abolidas, em que a divisão política no país era extrema e em que o aparelho de inteligência do Estado esteve a serviço da repressão de qualquer tentativa de revolta e agrupação política dissidente, a confiança da sociedade em seus governantes se encontrava profundamente fraturada.

Este cenário tenso se apresenta em uma parte significativa da obra através de narrativas conjecturais, opiniões, percepções, transcrições de relatos e livros, nos quais transparece uma atmosfera de desconfiança e insegurança onde toda afirmação é suscetível de suspeita. Em conformidade a essa sensação de incerteza, a macroestrutura da obra deixa entrever a situação política vivida neste período histórico.

Um exemplo concreto desta ambientação é a utilização de testemunhos; diante dos incríveis acontecimentos que rodearam a vida do piloto da força 
aérea Carlos Wieder, a exumação de testemunhos incertos é a única aproximação de que dispõe o leitor à sua enigmática figura. A maior parte do que é narrado se mostra parcial e subjetivo, versões e perspectivas de fatos que encontram no narrador um ponto de confluência, que serve como ouvinte de memórias confusas de membros do grupo literário como Bibiano O'Ryan, a Gorda Posadas, etc.

Todo lo anterior tal vez ocurrió así, tal vez no. Puede que los generales de la Fuerza Aérea chilena no llevaran a sus mujeres. Puede que en el aeródromo Capitán Lindstrom jamás se hubiera escenificado un recital de poesía aérea. Tal vez Wieder escribió su poema en el cielo de Santiago sin pedir permiso a nadie, sin avisar a nadie, aunque esto es improbable. Tal vez aquel día ni siquiera llovió sobre Santiago, aunque hay testigos (ociosos que miraban hacia arriba sentados en el banco de un parque, solitarios asomados a una ventana) que aún recuerdan las palabras en el cielo y posteriormente la lluvia purificadora. Pero tal vez ocurrió de otra manera. Las alucinaciones, en 1974, no era infrecuentes (IBIDEM, p. 92).

O manuseio dos modos discursivos do testemunho no romance se vê expressado por meio das constantes justificativas do narrador acerca da origem das versões que compõem como uma colagem a diegese:

¿Qué me contó Bibiano de la casa de Ruiz-Tagle? Habló de su desnudez, sobre todo; tuvo la impresión de que la casa estaba preparada (IBIDEM, p. 17)

¿Te diste cuenta de que era un Messerschmitt? Si tú lo dices, te creo, dije yo (IBIDEM, p. 40)

As diversas personagens contribuem com suas opiniões e fragmentos de história para construir a versão do narrador: essa delegação da responsabilidade do dito dá à narrativa um caráter móvel, que tende a iludir a sensação de veracidade, se tornando eco de vozes ausentes, cuja credibilidade de dissipa no contexto de uma atmosfera de desinformação.

O romance combina ao menos dois tipos de investigação: a literária e a policial, sendo que a primeira se apresenta como caminho para chegar até a segunda. Vale ressaltar que a historiografia literária que se mescla com a investigação policial é ficcional: apenas uma parte dos escritores, obras e 
movimentos literários mencionadas tem existência real ou histórica. Nesse sentido, percebemos que o relato policial aparece cruzado com outros discursos, assim como acontece em boa parte da obra de Bolaño (LoS detectives salvajes, La literatura nazi en América, etc.).

Essa insistência de Bolaño em incorporar elementos policialescos às suas narrativas parece uma tentativa de produzir um rendimento estético específico que, somado ao aspecto testemunhal do texto, dão uma sensação de fragilidade aos discursos, de modo a assegurar que o leitor não tome nada como absolutamente certo ou seguro.

La primera vez que vi a Carlos Wieder fue en 1971 o 1972 [...] Según Bibiano O'Ryan, era un tipo de facciones demasiado frías para ser hermosas, pero, claro, Bibiano afirmó esto a posteriori y así no vale [...] Daban una de Bergman, no recuerdo cuál [...] En la casa de Ruiz-Tagle lo que faltaba era algo innombrable (o que Bibiano, años después y ya al tanto de la historia 0 de buena parte de la historia, consideró innombrable, pero presente, tangible). (IBIDEM, pp.13, 15, 17)

Os "desacordos" com o literário que identificamos na obra do escritor chileno têm como pano de fundo um caráter que nos parece remeter a um âmbito que ultrapassa questões apenas estéticas e avançam por assuntos expressamente de ordem política. Sobre isso, Carlos Vargas Salgado, em seu artigo ¿La escritura del mal, o el mal de la escritura? Estrella distante de Roberto Bolaño, afirma, por exemplo:

Al mismo tiempo, la búsqueda estética no deja de lado la preocupación histórica e ideológica. Bolaño ha sentido en carne propia la persecución, la barbarie de la dictadura chilena, y el violento tren de la miseria. Nada de esto le permite hablar desde una torre de marfil. (SALGADO, 2011, p. 3)

Nessa perspectiva, o livro Bolaño por sí mismo contém uma série de afirmações do autor que apontam para certificar certa busca por uma dupla dimensão, estética e social, de Estrella distante. Ele esclarece que a crítica se refere não só ao fascismo ou à ultra direita, mas também se estende aos radicalismos de esquerda. Ele ataca, portanto, o fanatismo, seja qual for seu mote, e também o mundo grotesco da literatura: 
En La literatura nazi en América yo cojo el mundo de la ultraderecha, pero muchas veces, en realidad, de lo que hablo ahí es de la izquierda. Cojo la imagen más fácil de ser caricaturizada para hablar de otra cosa. Cuando hablo de los escritores nazis de América, en realidad estoy hablando del mundo a veces heroico, y muchas más veces canalla, de la literatura en general. (BRAITHWAITE, 2011, p. 111-112)

A crítica política serve a Bolaño para submergir-se na crítica literária. É por esta convergência do social e do estético, do discurso e da reflexão sobre a ditadura, de literatura e arte, que escolhemos como recorte desta pesquisa identificar em Estrella distante o modo como a violência de Estado figura no romance.

\subsection{Biopolíticas e a banalização da violência}

A fim de pensar de modo produtivo e criticamente a figuração da violência de Estado presente em Estrella distante, assim como em Amuleto e Nocturno de Chile, obras que analisaremos nos capítulos seguintes, tomaremos como ponto de partida o conceito de biopolítica, desenvolvido pelo filósofo Michel Foucault no fim da década de 1970 e posteriormente discutido, reelaborado e ampliado por outros filósofos. Para tal tarefa, nos centraremos, nos próximos parágrafos, no desenvolvimento e desdobramentos desse conceito.

Apresentado ao grande público em 1976, no último capítulo de História da Sexualidade I - A vontade de saber, e desenvolvido perante uma audiência restrita no curso proferido no Collège de France, também do mesmo ano, publicado posteriormente sob o título de Em defesa da sociedade, o conceito de biopolítica tardou quase duas décadas até ser realmente considerado e desenvolvido por outros pensadores (DUARTE, 2008). Foi apenas a partir da década de 1990 que o conceito de biopolítica passou a receber novos e originais desenvolvimentos, inflexões e aprofundamentos, engendrando linhas de investigação nem sempre concordantes entre si - como veremos adiante ao 
conhecermos as leituras do conceito de Roberto Esposito, Peter Pál Pelbart e Giorgio Agamben.

Usado por Foucault para referir-se às relações de poder desenvolvidas a partir do século XIX, o termo diz respeito a certo tipo de política que passa a ser centrada na vida, na individualidade do ser humano, e não mais no poder soberano e disciplinador nos moldes da Revolução Francesa. Surge assim um novo direito do Estado, o de "fazer viver e deixar morrer", em contraposição ao anterior direito de "fazer morrer e deixar viver". Se antes o poder soberano exercia seu direito sobre a vida na medida em que podia matar, de tal modo que nele se encarnava o "direito de fazer morrer ou de deixar viver", a partir do século XX se opera a transformação decisiva que dá lugar ao biopoder como nova modalidade de exercício do poder soberano, que agora será um "poder de 'fazer' viver e 'deixar' morrer".

O que há de contraditório nesse novo direito é que, em teoria, o poder do Estado e suas intervenções políticas devem servir para proteger a vida da população, mas, na prática, como essa proteção está baseada em ideais de manutenção da pureza e da ordem, ao mesmo tempo em que se protege a vida de uns, se autoriza a morte de outros. Assim, de acordo com a pesquisadora Susel Rosa, em seu artigo "A banalização da violência no contexto biopolítico do estado de exceção":

[...] a violência não diminui, mas se dissemina pelo corpo social e político. É uma violência depuradora que garante a vida de parte da população [...]. Nesse sentido, a política é vivenciada como violência, onde a vida humana pode ser descartada e assassinada por atos administrativos sem que se cometa qualquer crime. (ROSA, 2006, p. 219)

O que Foucault compreendeu e Rosa ressalta em seu trabalho é que a transformação da vida em elemento político por excelência, que teria de ser administrado, avaliado, regulado, regrado e regularizado, trouxe consigo um aumento e uma transformação no caráter da violência do estado. Em suma, Foucault descobriu que tal cuidado da vida trouxe consigo a exigência contínua e crescente da morte em massa, uma vez que é no contraponto da violência 
depuradora que se podem garantir mais e melhores meios de sobrevivência a uma determinada parcela da população.

Retomaremos adiante a discussão sobre o caráter depurador da violência de Estado. Agora, nos ateremos ao aprofundamento do conceito de biopolítica. O texto de Rosa não só atualiza o conceito apresentado por Foucault, como também destaca seu papel na sociedade contemporânea, pois sob a perspectiva biopolítica a vida passa a ser elemento político controlado pelo Estado, que determina legalmente o uso que fará desse elemento. Daí se fala também em um biopoder, ou poder total, que seria o poder do estado de administrar a vida e controlar o corpo. (IBIDEM, p. 218)

Essa nova forma de compreender e analisar o poder, introduzida por Foucault, já não parte do princípio contratualista da teoria da soberania, mas sim de uma analítica do poder, ou seja, o estudo das relações de guerra que atravessam inclusive a sociedade contemporânea. A continuidade do uso de mecanismos tanatopolíticos, teoricamente recursos de guerra, é percebida com frequência nas democracias latino-americanas contemporâneas. Vejamos, por exemplo, o caso dos jovens de Soacha na Colômbia, que ficou conhecido como "El escándalo de los falsos positivos".

\subsubsection{Descartabilidade da vida}

Ao final do ano de 2008, começam a aparecer relatos que envolviam membros do exército da Colômbia com o assassinato de civis inocentes para fazê-los passar como guerrilheiros mortos em combate dentro do conflito armado que vive o país. Esses assassinatos teriam como objetivo apresentar resultados por parte das brigadas de combate. Esses casos são reconhecidos dentro dos Direitos Humanos Internacionais como execuções extrajudiciais e no Direito Penal Colombiano como homicídios de pessoas protegidas. Apesar de existirem denúncias e especulações sobre estes fatos, foi apenas nos últimos meses de 2008, quando os cadáveres de 19 jovens que haviam desaparecido do município de Soacha, vizinho a Bogotá, apareceram como baixas do exército ao norte de Santander, que o escândalo veio à tona. 
Ao mesmo tempo, algumas ONGs denunciavam o começo de uma nova onda de "limpeza social" no país. Tudo isso em um contexto de um projeto político-militar que havia feito das práticas de morte sua estratégia privilegiada na "guerra contra os terroristas". Homens constituídos como inimigos da pátria, uma ameaça à segurança da nação e de cada um dos cidadãos e que, nesse sentido, devem ser aniquilados. Descartabilidade da vida como expressão de um regime excepcional que encontra sentido no direito soberano de "fazer morrer" o outro para "deixar viver" o igual: os "falsos positivos", os "descartáveis", simbolizam um regime que dá morte aos inimigos para produzir a vida normalizada.

\subsubsection{Foucault, Bolaño e o poder}

No entanto, Foucault não entende o poder como um bem que alguns possuem em detrimento de outros, tampouco o idealiza como uma essência com identidade singular; para ele, o poder é sempre plural, dependente das relações e é exercido por meio de práticas heterogêneas e sujeitas a alterações. Isso quer dizer que o poder se dá em um conjunto de práticas sociais estabelecidas historicamente, que operam através de dispositivos estratégicos que alcançam a todos e dos quais ninguém pode fugir, posto que não se encontra uma zona da vida social que seja isenta de seus mecanismos. Daí a atualidade e a relevância do pensamento foucaultiano no sentido de reconhecer a racionalidade que constitui ou guia o interior dos processos políticos do presente, referidos na narrativa ficcional de Bolaño e também em seus discursos, como vemos na coletânea de seus artigos e discursos Entre paréntesis, publicada postumamente, onde ele descreve melancolicamente 0 que vê na sociedade chilena:

Nada pidas que nada se te dará. No te enfermes que nadie te ayudará. No pidas entrar en ninguna antología que tu nombre siempre se ocultará. No luches que siempre serás vencido. No le des la espalda al poder porque el poder lo es todo. (BOLAÑO, 2009, p. 6) 
Essas considerações iam de encontro à concepção tradicionalista, jurídico-política, do poder como instância integradora da figura do Estado e do soberano, que funcionava apenas no sentido vertical de cima para baixo, impondo, por meio da repressão e da lei que diz não, o espaço do que era possível e permitido. Foucault não entende o poder nem como violência legalizada nem como violência que foge à lei, pois, de acordo com suas análises, as relações de poder não se constroem sobre relações legais, no nível do direito e dos contratos, mas sim no âmbito das disciplinas e seus efeitos de normalização e moralização.

As reações e resistências contra uma relação de poder sempre se dão a partir de dentro das redes de poder, em um choque de forças: onde existe poder, existe resistência, de modo que todo e qualquer lugar social pode ser campo de resistência, a partir de estratégias distintas. Na análise de Foucault, o corpo aparece como instância privilegiada de atuação dos micro poderes disciplinares, sendo entendido como a arena de batalha na qual se travam conflitos habituais entre as exigências da normalização disciplinar institucional e as linhas de fuga da resistência. Os micro poderes disciplinares acometem 0 corpo e atuam sobre ele, penetrando-o e forjando-o (FOUCAULT, 1988).

Foi somente no final do percurso genealógico de sua pesquisa que Foucault abordou os conceitos de biopoder e biopolítica, a fim de explicar o surgimento, ao longo do século XIX e, principalmente, na virada para o século $\mathrm{XX}$, de um poder disciplinador e normalizador que já não era exercido sobre os corpos de maneira individual, nem se encontrava disseminado na organização institucional da sociedade, mas se concentrava na figura do Estado e se exercia enquanto política estatal, com pretensões de administrar a vida e o corpo da população.

Em Estrella distante, Bolaño parece particularmente remeter a essa matriz do poder ao cruzar a arte e o horror do poder autoritário individualizado, a exploração dos corpos por meio da poesia visual. Carlos Wieder é a personagem central do romance. Trata-se de um piloto da força aérea chilena que, antes do golpe de 1973, se passava por mero expectador e aspirante a poeta em oficinas literárias, chamado Alberto Ruiz-Tagle. Após o golpe, seu 
desaparecimento concomitante ao sumiço de vários jovens poetas frequentadores das oficinas despertam no narrador Arturo Belano e seu colega Bibiano O'Ryan suspeitas sobre esse piloto excêntrico que desenhava poesias curiosas com fumaça de avião nos céus do país. Bibiano e Belano logo chegam à conclusão de que Ruiz-Tagle e Wieder são a mesma pessoa, e que ele é responsável pelo assassinato e sumiço de pelo menos duas colegas poetas. Ou seja, Wieder, amparado pelo aparato do Estado, comete crimes bárbaros em nome da manutenção da "ordem" social.

Voltando à tese de Foucault, ele afirma que desde o início do século XX, interessou (e interessa) ao poder estatal estabelecer políticas higienistas, através das quais será possível sanear o corpo da população, depurando-o de suas infecções internas. É aí que encontramos a evidência do diferencial no pensamento foucaultiano: aonde nossa consciência moderna, iluminista, nos levaria a enaltecer o caráter humanitário dessas intervenções políticas que pretendem incentivar, proteger, estimular e administrar a vida da população, no mesmo lugar Foucault enxergou a contrapartida cruel desta obsessão do poder estatal pelo cuidado depurador da vida.

Ele depreendeu que, a partir do momento em que a vida passou a ser o elemento político por excelência, que precisa ser administrado, calculado, gerido, regrado e normalizado, o que se observa não é o decréscimo da violência; pelo contrário, pois este cuidado com a vida traz consigo, necessariamente, a exigência contínua e crescente das mortes em massa, uma vez que somente no contraponto da violência purificadora se pode garantir mais e melhores meios de sobrevivência a determinada população. Reconhecemos insistentes exemplos do uso dessa violência depuradora em várias obras de Bolaño, como os homicídios dos poetas que representavam a nova literatura chilena em Estrella distante ou os feminicídios de "La parte de los crímenes" em 2666, por exemplo. 


\subsubsection{Depuração e monstros}

Não existe, assim, incoerência entre o poder de administrar a vida e o poder de matar milhões para garantir as melhores condições vitais possíveis, como proclamou Bauman: "toda aposta na pureza produz sujeira, toda aposta na ordem cria monstros" (BAUMAN, 2004, p. 158). Em sua tentativa de traçar um perfil das relações humanas e sociais no período contemporâneo, o qual denomina modernidade líquida, o sociólogo polonês Zygmunt Bauman acaba adentrando o tema do poder e da soberania. Para ele, a soberania que surge com os modernos Estados-nação está inextricavelmente limitada a um território, é impensável sem um "lado de fora". Os monstros criados na era da promoção da trindade território/nação/Estado foram responsáveis pela criação, por parte do Estado soberano, de mecanismos que adquirissem o direito de negar direitos, em nome da manutenção de uma suposta ordem.

A partir do momento em que a ação do soberano foi a de "fazer viver", ou seja, estimular o desenvolvimento da vida, e não apenas impor a morte, as guerras se tornaram mais sangrentas e os extermínios se multiplicaram:

As guerras já não se travam em nome do soberano a ser defendido; travam-se em nome da existência de todos; populações inteiras são levadas à destruição mútua em nome da necessidade de viver. Os massacres se tornaram vitais. Foi como gestores da vida e da sobrevivência dos corpos e da raça que tantos regimes puderam travar tantas guerras, causando a morte de tantos homens. E, por uma reviravolta que permite fechar o círculo, quanto mais a tecnologia das guerras voltouse para a destruição exaustiva, tanto mais as decisões que as iniciam e encerram se ordenaram em função da questão nua e crua da sobrevivência. (FOUCAULT, 1988, p. 129)

Foucault entende a guerra como o princípio histórico do funcionamento do poder; para ele, a guerra é o pano de fundo do exercício do poder político na sociedade. O poder político se constitui, então, no deslocamento da relação entre força bélica e o funcionamento de diversas práticas institucionais, econômicas e sociais, de tal maneira que todas as batalhas e enfrentamentos em um sistema político particular podem ser compreendidas como re-inscrições 
da guerra no corpo social. Falando de Estrella distante e pensando no contexto histórico no qual sua narrativa está inserida, percebemos que Bolaño faz diversas referências à Segunda Guerra Mundial no texto, a mais importante delas ao nazi-fascismo em si; também podemos pensar que as ditaduras latinoamericanas estavam inseridas no contexto mundial da Guerra Fria.

\subsubsection{Biopolíticas}

Para pensar a contemporaneidade ficcionalizada pelas obras de Bolaño, em que se inserem esses mecanismos destrutivos vinculados a diferentes formas de poder, iremos fazer a seguir uma pequena digressão argumentativa nesta dissertação, pois entendemos que devemos tratar e discutir alguns questionamentos sobre o conceito de biopolítica como foi apresentado por Foucault. Por um lado, sua analítica do poder o leva a propor o surgimento de uma nova tecnologia do poder que se centra na manutenção e proteção da vida da população; por outro, exatamente no momento em que política e vida se encontram em uma superposição tão estreita e a política entra na esfera da zoé (vida biológica), se desenvolve o maior desdobramento da morte da história da humanidade. Por que uma política da vida de torna ação de morte? Por que ao mesmo tempo em que se desenvolvem técnicas para a proteção e desenvolvimento da vida se registram guerras tão sangrentas e ferozes?

O filósofo italiano Roberto Esposito traça em Bíos algumas reflexões a respeito dessa contradição. Para ele, Foucault se encontra com esse paradoxo, mas nunca dá uma resposta clara a essas perguntas. Em algumas passagens de Em defesa da sociedade parece prevalecer a hipótese de descontinuidade entre ambas as tecnologias do poder (ESPOSITO, 2006). Por exemplo, ao se referir ao poder disciplinário, Foucault escreve:

Ora, nos séculos XVII e XVIII ocorreu um fenômeno importante: o aparecimento - deveríamos dizer a invenção - de uma nova mecânica do poder, que tem procedimentos bem particulares, instrumentos totalmente novos, uma aparelhagem muito diferente e que, acho eu, é absolutamente incompatível com as relações de soberania. (FOUCAULT, 2005, p. 42) 
$\mathrm{Na}$ verdade, se o poder soberano se ocupa do controle e expansão do território e da subtração de bens dos seus súditos, a disciplina ao contrário se concentra no adestramento e controle dos corpos - anatomopolítica do corpo humano. Desde esse ponto de vista a cisão entre ambas as tecnologias de poder não poderia ser mais clara: por um lado, se manifesta um poder de morte que subtrai as forças vitais de seus súditos; de outro lado, se desenvolvem técnicas de administração e potencialização dos corpos que prolongam a vida biológica dos seres humanos.

Esposito propõe resolver essa suposta antinomia do pensamento foucaultiano a partir do paradigma da imunização. Segundo ele, a imunidade é o ponto de cruzamento entre política e vida. A política surge apenas quando é necessário defender a vida, e a vida aparece apenas quando existe um poder que a proteja, ou seja, não há vida fora da biopolítica. Entretanto, a imunidade não seria apenas o ponto de relação entre o poder e a vida, mas também o poder de conservação da vida. Nesse sentido, o poder protege a vida através da eliminação de elementos ameaçadores, uma eliminação que assume o caráter de inclusão/exclusão. Portanto, a imunização é uma proteção negativa da vida (ESPOSITO, 2006).

Em outras palavras, o conceito de imunidade permite superar o modelo binário negativo-positivo da biopolítica. Os dispositivos positivos (produção de vida) e negativos (produção de morte) não estão em uma relação externa ou ocasional. Soberania e política, produção de vida e de morte, são mecanismos de poder que se articulam por meio de uma relação funcional. Se os sistemas sociais não funcionam descartando as diferenças, senão produzem-nas como antígenos para reativar seus próprios anticorpos, a imunização se converte em objeto da comunidade: a imunização protege a sociedade de si mesma. Portanto, a violência não se limitaria a preceder o direito nem a segui-lo, e sim o acompanharia ao longo de sua trajetória.

O filósofo Peter Pál Pelbart também nos apresenta, nos anos 2000, sua releitura da biopolítica. Para ele, o biopoder contemporâneo já não se ocupa de fazer viver ou morrer, mas sim de fazer sobreviver. A sobrevida seria a vida humana reduzida ao seu mínimo biológico, ao simples fato de existir, uma vida 
nua. Nesse sentido, Pelbart se aproxima dos conceitos do filósofo italiano Giorgio Agamben, como biós (individualidade) e zoé (vida que atravessa a todos):

\begin{abstract}
Pois não é mais a vida, não é mais a morte, é a produção de uma sobrevida modulável e virtualmente infinita que constitui a prestação decisiva do biopoder de nosso tempo. Trata-se, no homem, de separar a cada vez a vida orgânica da vida animal, o não-humano do humano, o muçulmano da testemunha, a vida vegetativa, prolongada pelas técnicas de reanimação, da vida consciente, até um ponto limite que, como as fronteiras geopolíticas, permanece essencialmente móvel, recua segundo o progresso das tecnologias científicas ou políticas. A ambição suprema do biopoder é realizar no corpo humano a separação absoluta do vivente e do falante, de zoé e biós, do não-homem e do homem: a sobrevida. (AGAMBEN , 2008)
\end{abstract}

Pelbart afirma que é um engano pensar em vida nua apenas para 0 muçulmano. Para ele, os comandantes dos campos de concentração também habitam essa zona intermediária entre o humano e inumano, pois a condição de sobrevivente é um efeito generalizado do biopoder contemporâneo que não se restringe aos regimes totalitários e inclui também a democracia ocidental, a sociedade consumista, a medicalização da existência, ou seja, a abordagem biológica da vida numa escala ampliada. (PELBART, 2007)

Nesse sentido, a teoria de Agamben também nos interessa especialmente enquanto releitura e reinterpretação do conceito de biopolítica, pois dá início às suas reflexões sobre o assunto a partir dos anos 90 , com a publicação de Homo sacer, se aproximando mais da contemporaneidade e do nosso corpus de trabalho. Além disso, diferentemente do que ocorre com Foucault, em Agamben o poder encontra-se intimamente vinculado ao Estado; este ocupa o espaço central de suas preocupações e atua como técnica de controle sobre os indivíduos enquanto sujeitos de uma determinada sociedade, como veremos em seu livro Estado de exceção. 


\subsection{O Estado de exceção como regra na contemporaneidade}

Em entrevista concedida à revista Carta Capital de 31 de março de 2004, Agamben, questionado sobre o porquê de haver declinado do convite para lecionar na Universidade de Nova Iorque devido à sua recusa em se submeter ao fichamento imposto pelos Estados Unidos, respondeu que sua reação fora motivada pela "preocupação com a escalada das práticas de controle, com o fato de medidas excepcionais estarem se tornando normais [...] provavelmente está se aproximando o momento em que todos os cidadãos serão 'normalmente' controlados pelo Estado do modo que antes se usava somente para criminosos, nas prisões". (AGAMBEN, 2004, p. 76)

Roberto Bolaño, ao receber o prêmio Rómulo Gallegos por Os detetives selvagens, enfatiza em seu discurso algo muito próximo à afirmação de Agamben: as falhas do processo revolucionário latino-americano e as atrocidades da violência de Estado:

[...] luchamos a brazo partido, pero tuvimos jefes corruptos, líderes cobardes, un aparato de propaganda que era peor que una leprosería, luchamos por partidos que de Haber vencido nos habrían enviado de inmediato a un campo de trabajos forzados [...] fuimos estúpidos y generosos, como son los jóvenes, que todo lo entregan y no piden nada a cambio, y ahora de esos jóvenes ya no queda nada, los que no murieron en Bolivia, murieron en Argentina o en Perú, y los que sobrevivieron se fueron a morir a Chile o a México, y a los que no mataron allí los mataron después en Nicaragua, en Colombia, en El Salvador. (BOLAÑO, 2004)

Inspirado pelo pensamento de Foucault e pelas reflexões de Hannah Arendt e Carl Schmitt, Agamben pensa a biopolítica no entrecruzamento de quatro conceitos da política ocidental: poder soberano, vida nua (homo sacer), estado de exceção e campo de concentração. A Foucault coube a descoberta do caráter biopolítico da política moderna a partir do século 19; porém, ele não chegou a se concentrar no estudo da principal instância biopolítica do século 20, os campos de concentração dos regimes totalitários. Hannah Arendt os analisou detidamente, mas, por sua vez, não foi capaz de compreendê-los em seu caráter biopolítico. A tarefa à qual Agamben se dedica é justamente 
desvelar o sentido da biopolítica a partir da análise da coesão existente entre os quatro conceitos citados, os quais perpassam toda a história da política ocidental e encontram, na modernidade, seu ponto máximo de saturação. (DUARTE, 2008)

A denúncia de Agamben se refere à semelhança de práticas adotadas pelos atuais regimes democráticos com as de um típico regime de estado de exceção que, "inicialmente apresentadas como medidas ligadas a acontecimento excepcionais, reservadas a situações limitadas no tempo e no espaço, tornam-se regra" (IDEM). Para exemplificar tais práticas, ele cita os USA Patriot Acts I e I/ e a Military Order, editados pelo governo de Bush em resposta aos atentados terroristas de 11 de setembro.

Essas medidas, adicionadas a projetos de criminalização dos imigrantes ilegais e outros envolvendo o combate ao terrorismo, demonstram, para Agamben, que o estado de exceção não deve mais ser compreendido como 0 próprio nome diz, isto é, como uma situação extraordinária invocada num momento de emergência, e sim, cada vez mais, como uma técnica de governo que, por ser aplicada normalmente à administração da vida, se ergue ao patamar de paradigma de governo nos atuais regimes democráticos.

Em Estado de exceção, Agamben traça uma genealogia desse tipo de prática a fim de demonstrar que suas origens remontam aos primórdios revolucionários do Estado democrático, à época da primeira Assembleia Constituinte Francesa (1789-1791), que instituiu o estado de sítio por decreto. Essa figura jurídica foi inserida, segundo ele, sob duas formas no novo conjunto de leis que instaurava o estado democrático sobre as ruínas do absolutismo: o estado de sítio militar, que protegeria a constituição e a democracia de quaisquer ameaças externas, se assim fosse necessário (em caso de guerras ou invasões), e o estado de sítio fictício, que seria aplicado com a intenção de eliminar possíveis conflitos internos - guerra civil, motins, insurreições, etc.

Em ambos os casos, o estado de sítio significaria a suspensão da lei com a justificativa de defesa da própria lei, um mecanismo extrajurídico de proteção da ordem jurídica, uma suspensão provisória e excepcional do regime 
democrático para a salvação da democracia, que se utilizaria da supressão dos direitos individuais dos cidadãos como única maneira de garantir a cidadania, e também da intervenção econômica no mercado como forma de garantir a liberdade de mercado.

Nesse sentido, percebe-se que, apesar de ter sido concebido a princípio como uma medida de salvaguarda temporária do estado democrático, o estado de sítio é um artifício essencialmente antidemocrático. Agamben identifica ao longo de seu trabalho um processo de deslocamento histórico em que essas medidas excepcionais passam cada vez mais a figurar como técnicas normais de governo, resultando na formação de um cenário político que de indeterminação, onde o estado de exceção se confunde com um estado de "guerra civil legal".

João Camillo Penna, em seu ensaio Estado de exceção: um novo paradigma da política?, identifica alguns exemplos contemporâneos do uso desse artifício:

\begin{abstract}
A guerra policial contra inimigos étnicos e/ou terrorismo, nos últimos anos, vem mobilizando a promulgação de estados de sítio permanentes em Israel (desde o início da Jihad palestina), nos Estados Unidos (o Patriot Act, na sequência dos ataques de 11 de setembro de 2001), na França (Nicolas Sarkozy, recentemente eleito presidente, iniciou, já como Ministro do Interior, uma política dura contra os imigrantes, sob o pretexto da alta dos índices de crimes pretensamente associados à imigração), e na Rússia (sob a ameaça de separatistas tchetchenos), para citar apenas alguns casos mais flagrantes.(PENNA, 2007, p. 182)
\end{abstract}

Também identificamos exemplos na América latina, mesmo após o fim das ditaduras militares que assolaram esses países na segunda metade do século XX. Além do já citado exemplo do caso dos "Falsos positivos" na Colômbia, encontramos situações inclusive no Brasil. Em seu romance-ensaio História natural da ditadura, Teixeira Coelho dedica um capítulo à defesa da tese de Agamben. O narrador da história afirma que o estado de exceção tenda a apresentar-se cada vez mais como paradigma predominante de governo na política contemporânea, e cita como maior exemplo dessa afirmativa as medidas provisórias brasileiras, instrumentos governamentais que são 
exatamente uma emanação da prática dos plenos poderes autoconcedidos pelos governos ditatoriais.

\subsubsection{Narrativas do Homo sacer}

Percebemos na obra ficcional de Bolaño vários indícios que vão ao encontro da tese de Agamben. Em Estrella cercana, o crítico José Manuel Lopez de Abiada faz a seguinte afirmação sobre a ambientação do romance póstumo de Bolaño, 2666:

[...] Santa Teresa es heterónimo y trasunto de Ciudad Juárez, espacio que en la ficción bolaniana aparece desplazado hacia el interior del desierto, sinécdoque del infierno en el que "arde" la ciudad. Una "ciudad doliente" - dicho sea en lo que sigue al hilo de conocidos sintagmas dantescos - en la que la barbarie de los feminicidios parece perpetuarse sine die y generar un "eterno dolor" perpetrado por sicarios o asesinos a sueldo "perdida gente"- que prestan sus servicios al narcotrafico29. Y es también metáfora y sinécdoque de un Estado de derecho fallido, de un Estado (valga la redundancia) en estado de excepción parcial, un Estado del que se podría sospechar que ha abolido o derogado parte de su ordenamiento jurídico. (ABIADA, 2012, p. 28)

Em Estrella distante, os espaços são reconhecíveis, porém os fatos que ocorrem são imprecisos; nesse sentido, a escritura parece duplicar o espaço político chileno, claramente perturbado. Ao longo do romance, a personagem Carlos Wieder se dedica a eliminar partidários de Salvador Allende, principalmente artistas e poetas: o assassinato das irmãs Garmendia é o início de uma cadeia de crimes funcionais do regime militar para eliminar seus adversários políticos. Nesse sentido, a violência de Estado ficcionalizada assume igualmente um caráter depurador, como indicam os teóricos da biopolítica. Para entendermos melhor como funciona essa esquemática na obra de Bolaño, utilizaremos um conceito que chamaremos de "lógica da depuração". 


\subsection{Vanguardismos e a lógica da depuração}

O filósofo francês Alain Badiou nos apresenta, em seu livro O século (2007), uma tese muito interessante que nos serve da mesma maneira como um eixo produtivo de análise e inteligibilidade da obra de Bolaño, particularmente Estrella distante. A filosofia de Badiou e a ficção de Bolaño aparecem como dois modos particulares de pensar e refletir sobre a questão da destruição e da criação artística.

Em Estrella distante, a suposta identificação da arte com o real está personificada em um de seus protagonistas, Carlos Wieder, que representa no romance a ideia da arte como práxis política, da arte pura e da arte de vanguarda. Deste modo, entendemos que Bolaño constrói uma ficção que se apresenta como uma reflexão estética e política sobre a "lógica da depuração" da arte, ou a relação entre arte e destruição.

Sobre a dimensão política e ética da obra de Bolaño, e sobre a relação específica desta dimensão com a estética particular do autor, Manzoni afirma que ele "se propone preguntas que resuelve con originalidad y audacia: de qué manera la ficción puede contar lo político, cómo narrar el horror, cómo construir una memoria y una escritura que trastorne los límites entre lo manifiesto y lo subyacente" (MANZONI, 2006, p.14). Em Estrella distante, o horror dos atos de Wieder e, consequentemente, da ditadura, apenas subjazem em descrições e testemunhos, assim como subjaz a relação entre vida e terror que Badiou irá abordar mais adiante.

Em O século, Badiou afirma que uma das grandes preocupações do século $X X$ foi pensar a relação entre violência real e o que ele chama de aparente semblante, ou seja, "entre rosto e máscara, entre nudez e travestimento" (BADIOU, 2007, p. 81). Tal aspecto pode ser percebido em registros de variados estilos, da teoria política à arte. Com relação à arte, Badiou se refere aos marxistas do século e sua valorização do conceito de ideologia. Para ele, "o próprio conceito de ideologia cristaliza a certeza 
científica de que as representações e os discursos devem ser lidos como as máscaras de um real que eles denotam e dissimulam" (IBIDEM, p. 82).

Em contrariedade aos ideais positivistas do século anterior, o século $X X$ descobre e trabalha em cima do poder da ignorância, do desconhecimento. A arte deste século se distancia do real porque entende que aí está a força da sua representação, posto que ele só opera por meio de ficções, montagens, máscaras. Para Badiou, esse distanciamento é um axioma da arte no século, especialmente da arte vanguardista.

Se a arte é o encontro de um real pelos meios exibidos do factício, então a arte está por toda a parte já que toda a experiência humana é atravessada pela distância entre a dominação e a ideologia dominante, entre o real e seu semblante. Por todo canto há exercício e experiência dessa distância. É a razão pela qual o século XX propõe gestos artísticos anteriormente impossíveis ou apresenta como arte 0 que anteriormente era mero dejeto. (IBIDEM, p. 84)

As vanguardas surgem no início do século $X X$, primeiramente enquanto corrente artística, como um novo modo de representação de formas iconoclastas da "paixão pelo real" característica do século; contudo, logo essa corrente inunda o pensamento coletivo, ultrapassando a fronteira da estética, tornando-se fenômeno de sociedade, referência de opinião: "a arte, para as vanguardas, é muito mais do que produção solitária de obras geniais. É questão da existência coletiva, é questão da vida. A arte não se concebe sem violento militantismo estético." (IBIDEM, p. 203)

O que caracteriza toda e qualquer vanguarda é uma ruptura formal com o sistema anterior. A vanguarda artística do século XX pretendia romper com a ideia do belo difundida ao longo do século XIX, se posicionando como exceção das regras de produção e circulação da arte. Enquanto portadora de poder de destruição do consenso formal, a vanguarda embute agressividade, elementos de provocação, gosto pelo escândalo (IBIDEM).

Bolaño foi um grande entusiasta das vanguardas. No Primer Manifiesto Infrarrealista, escrito por ele em 1976, assinala que "Certeza de que todo está nombrado, develado, miedo a descubrir [...] conciencia de que nos acercamos 
a $200 \mathrm{~km}$ por hora al cagadero o a la revolución [...]" (BOLAÑO, 1976). Encarando o fatalismo de uma época que presenciaria o esgotamento de qualquer impulso renovador, Bolaño repetia o gesto fundador de toda vanguarda, mas o matiza com uma certeza: a impossibilidade da originalidade. Ainda assim, levanta em seguida a possibilidade da subversão ao denunciar o medo de descobrir algo próximo ao novo, situando o poeta entre duas possibilidades fatais, a revolução ou o "cagadero".

Seguindo a reflexão sobre a vanguarda, Badiou nos instiga a pensar o par destruição/subtração pelos caminhos da arte. Fruto da antecipação da negatividade vivida no final do século anterior, a arte do século $X X$ trabalha de maneira diferenciada sua relação com o real, conforme já afirmamos. Para trabalhar o tema, Badiou recorre a uma breve análise de uma obra icônica do suprematista ucraniano Kazimir Malevich.

Em 1918, o artista pinta Quadrado branco sobre branco (ou Quadrado branco em fundo branco). Badiou utiliza esse exemplo a fim de ilustrar o protocolo do pensamento subtrativo: "elimina-se a cor, elimina-se a forma, mantém-se somente alusão geométrica que comporta diferença mínima, a diferença abstrata entre fundo e forma, e principalmente a diferença nula do branco com o branco [...]" (BADIOU, op. cit., p.93). Nesse sentido, há subtração ao invés de destruição; há um apagamento de todo o conteúdo, que trata o real a partir do distanciamento, e não de sua negação. Para Badiou, coexiste no século outro tipo de arte que se identifica com o real de forma diferenciada, que tenta desmascarar suas cópias e falsos semblantes por meio da destruição.

As vanguardas estavam muito ligadas ao desenvolvimento da sociedade industrial e dos poderes das máquinas, a exemplo das relações entre futurismo e fascismo. Günter Anders, em Nosotros los hijos de Eichmann, afirma que já não somos capazes de criar a representação da força destrutiva de nossos atos.

En sí misma, nuestra capacidad de producir en muy grandes cantidades, de construir máquinas y ponerlas a nuestro servicio, de construir instalaciones, de organizar administraciones y coordinar organizaciones, etc, no es algo monstruoso, sino grandioso. ¿Cómo y por qué motivo puede conducir a lo monstruoso? Respuesta: porque el triunfo de la 
técnica ha hecho que nuestro mundo, aunque inventado y edificado por nosotros mismos, haya alcanzado tal enormidad que ha dejado de ser realmente nuestro en un sentido psicológicamente verificable. Ha hecho que nuestro mundo sea ya demasiado para nosotros. (ANDERS, 2001, p.17)

Aqui voltamos a nos referir à personagem central do romance de Bolaño: Alberto Ruiz-Tagle/Carlos Wieder, o poeta-assassino. É nesse jogo de duplos que está o fio condutor da história narrada e, no nosso entendimento, da relação entre arte e depuração (violência depuradora), entre estética e política. A atividade artística exercida pela personagem no período da ditadura, se comparada ao que ele produz já na fase democrática da história, nos permite pensar na existência de um projeto poético, uma proposta estética que atravessa as coordenadas de uma racionalidade política fundada na destruição de vidas.

Ruiz-Tagle/Wieder comenta com suas amigas poetisas que ele revolucionará a poesia chilena, e que esta nova poesia não é a que ele irá escrever, e sim a que irá fazer. Para ele, a poesia deve ser uma nova ação, e para que isso seja possível será necessário destruir a poesia precedente, começar do zero. Para dar forma à sua revolução poética, Wieder identifica a poesia com seus poetas; deste modo, destruir e superar a poesia precedente implica, necessariamente, em assassinar seus poetas.

Badiou afirma que tanto a destruição como a subtração enquanto atos artísticos têm uma finalidade específica no cenário do século XX. Na categoria da pintura, o quadro de Malevich representa o cúmulo do termo que ele afirma ser uma das grandes palavras de ordem do século e que nos servirá de eixo para uma possibilidade de leitura de Estrella distante: a depuração. Tanto subtração quanto destruição implicam em depurar a correlação entre uma categoria e seu referente, entre real e representação. No entanto, o ato de destruição artística tenta captar a identidade do real por meio de seu desmascaramento, tendendo assim ao nada ou à morte como único modo de liberdade pura. Para Badiou, esse esquema de pensamento, que ele denomina de lógica da depuração, só se tornou dominante no século pela presença da destruição enquanto sinal primeiramente político. 
Badiou entende que o século XX foi motivado pela tentativa de mudar o homem, de criar um homem novo. Para elucidar esse entendimento, cita ao longo do seu texto alguns projetos nesse sentido que, para ele, fracassaram: um retorno a origem pura (o homem ariano do nazismo); a de um homem que jamais haveria tido lugar na história, o homem pleno e livre do socialismo; ou ainda um homem que não se dá como projeto, mas como animal lastimável (BADIOU, op. cit., p.264), um anti-projeto que visa bloquear toda a alternativa que não seja a da política única liberal, com o risco de reincidirmos no terror nazista ou stalinista.

Ao longo das leituras apresentadas no livro, compreendemos que Badiou tenta mostrar o que havia de questionável nesses projetos. A primeira análise na qual o autor se detém se refere a um poema de 1923, O século, do poeta russo Ossip Mandelstam, que vale ser citado aqui em sua totalidade:

Século meu, besta minha, quem poderá

Mergulhar os olhos em tuas pupilas

E colar com seu sangue

As vértebras de duas épocas?

O sangue-fundador aos borbotões

Vomita coisas terrestres.

O vertebrador quando muito freme

No limiar dos novos dias

Enquanto vive a criatura

Deve esgotar-se até o fim

E a vaga brinca

Com a invisível vertebração.

Como a tenra cartilagem de uma criança

É o século caçula da terra.

Em sacrifício uma vez mais, como o cordeiro,

É oferecido o sincipúcio da vida. 
Para arrancar o século de sua prisão,

Para começar um mundo novo,

Os joelhos dos dias nodosos

É preciso que a flauta os uma.

É o século, se não, que agita a vaga

Segundo a tristeza humana,

E na erva respira a víbora

Ao ritmo de ouro do século.

Uma vez mais os botões vão bojar

O renovo verde irromper,

Mas tua vértebra está rompida,

Meu pobre e belo século!

E com sorriso insensato

Olhas pra trás, cruel e fraco,

Como uma besta ágil outrora

As pegadas de seus próprios passos.

(BADIOU, op. cit., p. 28-29)

A figura da besta perpassa todo o sentido do poema. Badiou entende que o poeta constrói assim uma visão orgânica do século, e não mecânica, subjetivando o século como composição viva. A vida seria então a maior questão ontológica do século que se inicia. Nesse ponto, Badiou inclui o pensamento do Nietzsche em sua reflexão: o super-homem do filósofo alemão é tido como uma antecipação do homem novo sonhado pelo século $X X$, relacionado diretamente aos questionamentos sobre o que seria o viver, a verdadeira vida.

Para Badiou, Vida e História não estão apenas relacionadas, mas se confundem: "É que Vida e História são dois nomes para a mesma coisa: o movimento que arranca da morte, o devir da afirmação" (IBIDEM, p.31). Ele 
afirma que o século XX propôs sua própria visão sobre o que é a História; essa ideia de mudança do sentido e do tempo histórico apresenta um homem que já não aceita ser um passivo da História que "engole", não aceita mais se submeter aos mandados dela. Sendo assim, o século - e o homem do século se torna voluntarista. Nietzsche tem como tema central de seu pensamento sobre o novo homem essa relação entre vida e vontade (vontade de poder): 0 homem só realiza seus desígnios a partir do momento que passa a coagir a História, forçando-a a nos servir. Daí surge uma tensão entre a necessidade vital/coação histórica e a teoria da descontinuidade voluntarista, como bem ilustra Badiou:

O que é preciso ver é que a imposição à continuidade vital de um heroísmo da descontinuidade se resolve, politicamente, na necessidade do terror. A questão subjacente é a relação entre vida e terror. O século sustentou sem tremer que a vida não realizava seu destino (e seu desígnio) positivo a não ser pelo terror. Daí uma espécie de reversão entre a vida e a morte, como se a morte fosse apenas o meio da vida. O poema de Mandelstam é perpassado por essa indecidibilidade entre a vida e a morte. (IBIDEM, p. 34)

Por meio da ação de Wieder, Bolaño ficcionaliza dois gestos: primeiro, o de uma vanguarda destrutiva, cuja condição de existência é a eliminação/morte de toda forma anterior, materializada em seus poetas; em segundo lugar, o próprio gesto da ditadura, em sua intenção de apagar toda a tradição política e suas manifestações de resistência por meio da tortura e do assassinato.

A identificação efetuada por Wieder entre poesia e poetas no romance, uma identificação até absurda e macabra, é descrita por Badiou como "uma paixão pelo real que é identitária", que tenta "apreender a identidade real, desmascarar suas cópias, desacreditar falsos-semblantes. É paixão pelo autêntico [...] que só pode realizar-se como destruição. É sua força porque, afinal das contas, muitas coisas merecem ser destruídas. Mas é também seu limite, porque a depuração é processo inacabável, figura do mal infinito" (IBIDEM, p. 94). 


\subsubsection{Arte e destruição}

Em 11 de setembro de 1973 tem início na história do Chile um processo de depuração, no qual o espaço político é destruído, apagado; a depuração realizada pelo Golpe militar aparece, utilizando a imagem criada por Badiou, como essa "figura do mal infinito". Em Estrella distante, o uso do aparato da ficção parece projetar uma crítica ao regime ditatorial, principalmente por meio do relato da biografia artística de Wieder: seus atos poéticos funcionam no espaço do romance, do mesmo modo como na ditadura funcionou o espaço social. Por meio da descrição das ações poéticas de Wieder, Bolaño questiona o caráter vanguardista do Golpe e denuncia a estetização da política e da morte empregada pela personagem.

A primeira ação poética de Wieder ocorre logo depois do Golpe, na cidade de Concepción. Ele escreve no ar, com fumaça de avião, o começo do livro bíblico de Gênesis em latim: "IN PRINCIPIO...CREAVIT DEUS...COELUM ET TERRAM" (BOLAÑO, 1996, p. 36). Esse desenho aéreo representa a condição da existência de sua revolução: como o universo descrito no Gênesis, a nova poesia deve surgir do nada, ex nihilo. Wieder quer inaugurar uma nova ordem, uma no qual o fazer e o ser da poesia se definam desde a oficialidade da ditadura militar, de uma maneira completamente vanguardista. $O$ piloto surge em pleno ar como o "Deus" da nova poesia chilena e seus primeiros versos aéreos aparecem perante os leitores como o gênesis dessa criação ex nihilo. Tanto no caso do Golpe como nos atos poéticos de Wieder, o novo aparece enquanto consequência da destruição: para que esse novo surja, é necessário fazer desaparecer todo o passado nacional.

Como o Quadrado branco sobre branco de Malevich, a próxima ação poética de Wieder poderia ser apreciada como uma encenação, por parte de Bolaño, da arte que pensa a si própria e se defende. A personagem pretende que este ato, o primeiro realizado na capital chilena e o último de sua carreira como poeta dos ares, apareça ao mesmo tempo como manifesto e poesia, pois aposta que sua recepção gere uma reflexão que provoque uma re-ação, que 
seja ao mesmo tempo teoria e prática. É nessa ação poética onde Bolaño conecta o processo de depuração realizado por Wieder no campo artístico com as mortes e desaparecimentos ocorridos na ditadura militar. No livro sobre Bolaño organizado por Celina Manzoni, Marcelo Cohen assinala, por exemplo, simetrias entre Wieder e o regime ditatorial:

Máquinas y misterio: si Estrella distante cuenta el desarrollo de un posible vanguardista ideal, el que realiza el asesinato de la lengua en el despedazamiento de cuerpos, lo cuenta en el marco perfecto - una máquina política de limpieza social - para sus fines de sobria ironía (COHEN in MANZONI, 2006, p. 34).

O romance de Bolaño ilustra então, com esse ato poético realizado por Wieder em Santiago, uma ligação de certo modo perversa entre poesia e política: nos versos escritos no céu, a morte é apresentada como a nova arte de vanguarda no novo regime. Ao juntar as frases soltas escritas com fumaça, nos deparamos com o seguinte texto:

La muerte es amistad

La muerte es Chile

La muerte es responsabilidad

La muerte es amor

La muerte es crecimiento

La muerte es comunión

La muerte es limpieza

La muerte es mi corazón

Toma mi corazón

Carlos Wieder

La muerte es resurrección

(BOLAÑO, op. cit., pp. 89-91)

Percebemos no poema de Wieder a defesa do caráter depurador da morte. Ele se recolhe à retórica e à ideologia do regime ditatorial mediante a estetização da morte e da glorificação de signos pátrios (além dos versos já citados, Wieder escreve sobre os céus da base antártica chilena Arturo Prat "La 
Antártida es Chile", além de outros versos sobre a pátria). Sobre a estetização e celebração da morte em Estrella distante, falaremos adiante no seguinte item deste capítulo.

Como ato artístico final, Wieder monta em seu apartamento uma exposição de fotos de pessoas torturadas e assassinadas por ele mesmo, como complemento prático da poesia anteriormente desenhada nos céus. Essa exibição é apresentada e um grupo seleto de oficiais chilenos e é descrita pelo próprio Wieder como "poesia visual, experimental, quintaesenciada, arte puro [...]" (IBIDEM, p. 87). Trata-se de uma exposição de uma série de fotografias de corpos mutilados, a maioria mulheres, que são descritas como "maniquíes, en algunos casos maniquíes desmembrados, destrozados, aunque Muñoz Cano no descarta que en un treinta por ciento de los casos estuvieran vivas en el momento de hacerles la instantánea...la impresión que provocan en quienes las contemplan es vivísima" (IBIDEM, p. 97).

As ações poéticas de Wieder se articulam como uma emulação do regime militar, que o autoriza a atuar publicamente como o poeta de vanguarda da ditadura. Sua poesia se apresenta como perversão justamente porque através dela Wieder tenta transformar em arte as torturas e assassinatos cometidos durante a ditadura, purificando-os. Assim, a narrativa parece nos dizer que a arte assassina de Wieder não é criação, é antes representação/mímesis do outro.

\subsection{Tanatopolítica, violência e arte}

Os primeiros sete capítulos de Estrella distante são ocupados por uma série de biografias tragicamente encerradas. Mas algo estranho acontece com elas: longe de iluminar as vidas que narram, terminam por transformar-se em uma rede de equívocos, povoadas de duplos e contadas por um narrador que mostra, sem grandes problemas, sua pouca fiabilidade. As biografias dialogam

entre si, se encostam, se complementam e, ao mesmo tempo, se contrapõem, cobrindo uma ampla zona da história chilena durante a ditadura de Pinochet. 
Nesta primeira parte traça-se também um provável itinerário para Wieder. O ingresso da figura do militar coincide com o ocultamento textual de Alberto Ruiz-Tagle, companheiro do narrador na oficina literária, sugerindo assim a identificação entre ambas as personagens. Entram em cena a partir daí a suspeita e a presunção; assim como as outras, a biografia de Wieder se sustenta sobre memórias fragmentadas, pistas falsas, comentários borrados e rostos indefinidos.

No romance, a morte irrompe na figura de Wieder - militar, poeta e assassino serial -, síntese absurda entre violência e arte. Um narrador exilado, uma série de biografias atravessadas pela história chilena, um assassino vestido de militar, um rastro de fumaça no céu e, enquanto isso, a literatura se faz presente por meio da figuração da morte: assim como Wieder, o narrador encontra na morte o motor de sua escritura, uma vez que só após a suposta morte do militar ele afirma ser capaz de narrar sua versão da história.

Para pensarmos como está figurada a morte no discurso ficcional de Bolaño, nos basearemos no conceito de tanatopolítica, ou seja, a política da morte, uma prática política que consente o extermínio como estratégia. Nesse sentido, para Agamben, não existe mais um limite entre bio e tanatopolítica no mundo contemporâneo:

$\mathrm{Si}$, en todo Estado moderno, hay una línea que marca el punto en el que la decisión sobre la vida se hace decisión sobre la muerte y en que la biopolítica puede, así, transformarse en tanatopolítica, esta línea ya no se presenta hoy como una frontera fija que divide dos zonas claramente separadas: es más bien una línea movediza tras de la cual quedan situadas zonas más y más amplias de la vida social, en las que el soberano entra en una simbiosis cada vez más íntima no solo con el jurista, sino también con el médico, con el científico, con el experto. (AGAMBEN, 1998. pp. 155-156)

Cada prática tanatopolítica funciona a partir de certo marco jurídico - o da "excepcionalidade" - e discursivo - a construção de uma alteridade negativa. O discurso é fundamentado no mecanismo do medo, que afeta se não somente, mas certamente com muito mais força, apenas determinados grupos sociais. Assim, entendemos que as práticas da morte tem funções políticas e sociais, pois além de se desdobrarem a partir de modelo de 
alteridade política (terroristas, por exemplo), também se desenvolvem a partir de um modelo de alteridade social, os descartáveis, a população "marginal". Enquanto a função política do tânatos contemporâneo se inscreve diretamente no marco discursivo, jurídico e simbólico da "guerra contra o terrorismo", a função social mantém uma relação com a metáfora de uma sociedade enferma, que requer um tratamento especial, separando o "normal" do "anormal", eliminando-o quando necessário e restituindo a "saúde" do corpo social.

Assim como os atos de violência narrados em Estrella distante retroagem à atmosfera do Chile dos anos 70 e às histórias específicas das práticas de repressão nesse período, a escritura no céu no contexto da poesia chilena inscrito insistente e cuidadosamente na narrativa nos remete ao que 0 poeta Raúl Zurita realizou nos céus de Nova lorque em 1982. Porém, há uma diferença marcante entre 0 ato de Zurita e o ato de Wieder; nos versos do poeta chileno, escritos com fumaça branca no céu azul de Manhattan, as palavras "hambre, nieve, desengaño, carroña, paraíso, pampa, cáncer, vacío, herida, gheto, dolor" culminam em um claro "MI DIOS ES MI AMOR DE DIOS". O que escreve Wieder é a transformação do horror fascista em ato poético, pois temos um assassino que, ao invés de unir vida e literatura, como advogam Zurita e as vanguardas em geral, une literatura e morte: "la muerte es amistad, es Chile, responsabilidad, amor, crecimiento, comunión, limpieza, mi corazón, la muerte es resurrección" (BOLAÑO, 1996, pp. 89-91). Chiara Bolognese esclarece da seguinte maneira a diferença entre os atos de Zurita e Wieder:

Wieder encarna la maldad absoluta y sus versos evocan la 'destrucción total'; mientras que los versos de Zurita, a pesar de su intenso dramatismo, muestran con frecuencia cierta esperanza en una posibilidad de salvación. Y es precisamente esta idea de la salvación lo que lleva a Zurita a adoptar esa actitud mesiánica que a Bolaño le disgustaba en este poeta que, por lo demás, le parecía destacable. En la misma línea de lectura, cabe destacar que los versos de Wieder aluden a las desaparecidas, al igual que muchos versos de Zurita: la diferencia estriba en que Wieder es el asesino, mientras que Zurita es la víctima de la violencia. Wieder cumple las órdenes de los jefes militares, Zurita se opone a ellos y a todo lo que proclaman. (BOLOGNESE, 2010, p. 263) 
Compreendemos a personagem de Wieder como a síntese do tânatos no romance. María Luisa Fischer afirma que "En Ruiz-Tagle/Wieder se reúnen la abyección con el arte; la barbarie y los actos civilizados [...]" (FISCHER in SOLDÁN e PATRIAU, 2008, p. 148). Desta maneira, podemos afirmar que a personagem central do romance é um duplo de si mesmo: tem duplo nome, dupla personalidade, uma vida dupla. Do mesmo modo, o romance joga com os eixos ficção/realidade, literatura/vida, literatura/morte, eu/o outro, fascinação/espanto, atração/repulsão, além do clássico latino-americano civilização/barbárie, jogo esse onde o binarismo se move constantemente. Acima de tudo, o autor parece expressar no romance o sentido de mal-estar que produz a incapacidade de distinguir os limites entre o bem e o mal. Nessa linha, sobre o vínculo entre estado fascista e arte, Ignacio Lopez-Vicuña afirma:

Wieder funciona como una especie de metáfora del fascismo, entendido éste como una imagen invertida del concepto de revolución de los jóvenes poetas izquierdistas. La voluntad revolucionaria de Wieder pone en escena los conceptos de violencia, destrucción y fundación de un nuevo orden, comunes a las vanguardias políticas y artísticas, pero transmutados en una pesadilla que prefigura la violencia militar de las dictaduras del cono sur y su creación de un nuevo orden económico, social y cultural. En este sentido, las metáforas del fascismo en Bolaño no representan un movimiento político preciso, sino más bien algo así como una voluntad, una oscura fuerza abocada a la destrucción creativa. (LÓPEZ-VICUÑA, 2009, p. 5)

Outro aspecto do tema dos duplos tem a ver com a repetição de eventos históricos e, em particular, a inscrição do contexto histórico da Alemanha nazista que abunda no romance: o relato de Wieder é uma extensão do primeiro capítulo de La literatura nazi en América, além de a personagem voar em um Messerschmitt 109 da Luftwaffe sobre Concepción em seu primeiro ato de escrita celeste; o parente de Juan Stein é um general judeu que enfrentou as tropas de Hitler; Bibiano O'Ryan desenvolve etimologias alucinadas acerca da origem alemã do nome Wieder; os jovens neonazistas que esfaqueiam Diego Soto na estação Perpignan; a imperturbabilidade de Wieder que lembra a de Adolf Eichmann; entre outros. 
Ademais da narrativa dos episódios ambientados nos anos 1970, ainda que não de acordo com os mesmos moldes, o romance parece enunciar uma continuidade política/artística entre os anos da ditadura e a recente história da democracia. Nesse sentido, o último capítulo é revelador. Nele não é mais a paisagem da América do sul que aparece, com sua natureza sublime e poética por excelência, mas sim a natureza doméstica de Blanes, um povoado da costa espanhola. Essa paisagem, na qual o narrador e o detetive contratado para encontrar Wieder encerram o cerco sobre ele, se caracteriza por um "cielo ideal", uma noite "hermosa y serena", e um mar dócil (BOLAÑO, op. cit., pp. 151-156). Esta diferença entre duas paisagens tão distintas aparece concomitantemente à aparição repentina e violenta de elementos que acentuam o caráter de artefato ficcional da obra. O último capítulo surge como manifesto da tensão que percorreu toda a história, pois, junto com o poeta, parece morrer também a poesia que, como a violência, não se corrige (BOLAÑO, 2007). As descontinuidades entre passado e presente propostas por Bolaño em seu texto ficcional possuem um denominador comum: a violência. A violência dos anos 1970 e 1990, que mantém unido o nó entre poesia e política, e que aparece na obra do chileno como fio condutor de um esboço de reconfiguração da paisagem nacional. 


\section{Poesia e (resistência à) violência em Amuleto}

La violencia es como la poesía, no se corrige.

No puedes cambiar el viaje de una navaja ni la imagen del atardecer imperfecto para siempre.

(Roberto Bolaño, La universidad desconocida)

\subsection{Amuleto}

Em geral, as narrativas de Bolaño dialogam com a criminalidade extrema, entendida como resultado do atual estado de emergência da violência em todos os âmbitos, consequência do despacificação da vida cotidiana no contexto biopolítico contemporâneo, conforme discutido por Agamben e outros teóricos no primeiro capítulo. À medida que exibem violações da ordem, esses textos constroem seus eixos dramáticos a partir de múltiplas e significativas experiências do horror: a ditadura chilena em Estrella distante, a invasão da UNAM em Amuleto, os assassinatos em Santa Teresa em 2666, entre outros.

Ao criticar continuadamente o establishment literário e sua submissão ao poder totalitário das ditaduras latino-americanas dos anos 1960 e 1970, Bolaño se utiliza de estratégias discursivas peculiares para narrar a experiência extrema da opressão. Para tratar desse assunto no escopo de nossa pesquisa, nos apoiaremos no romance Amuleto, publicado pela primeira vez em 1999.Este romance aborda um período chave na gestação da geração poética latino-americana da década de 1970.

No fim da década de 1990, Bolaño nos apresentou o texto que faria sua produção narrativa tornar-se uma das mais importantes no contexto latinoamericano dos últimos anos: Os detetives selvagens, de 1998. A obra dá voz a 53 narradores; dividida em três partes, a primeira e a terceira são o relato da vida do jovem poeta Juan García Madero, enquanto a segunda parte se constitui de relatos confessionais de diversos outros artistas. Surgido de uma 
das confissões da segunda parte do livro, Amuleto funciona como ampliação do testemunho de Auxilio Lacouture, poetisa uruguaia exilada no México.

Dois marcos históricos aparecem como pano de fundo da história do romance: o massacre de Tlatelolco e o golpe militar chileno de 1973 (este também pano de fundo de Estrella distante). A invasão da Universidad Autónoma de México e o consequente massacre de Tlatelolco ocorreram no dia de 2 de outubro de 1968 na Plaza de las Tres Culturas, em Tlatelolco, cidade do México, a apenas dez dias do início dos Jogos Olímpicos que foram disputados na mesma cidade. Neste dia, o exército mexicano reagiu de forma violenta a uma manifestação pacífica de estudantes, que protestavam contra a política do governo de Gustavo Díaz Ordaz. Até hoje, o verdadeiro número de mortos permanece incerto, sendo que algumas fontes apontam para mais de mil mortos, enquanto a maioria delas aponta para um número entre 200 e 300 mortos, e fontes governamentais se referem a 40 mortos e 20 feridos. Além dos mortos e feridos, milhares de pessoas foram detidas.

\subsection{A voz de Auxilio: relato marginal}

Auxilio Lacouture, a personagem-narradora de Amuleto define os contornos do seu próprio relato já no primeiro capítulo da obra. Explica que a sua história será uma "historia de terror", "una historia policíaca, un relato de serie negra y de terror" (BOLAÑO, 2009, p. 11). Ao mesmo tempo em que anuncia essa ordem do discurso, afirma que, ainda assim, não parecerá: "No lo parecerá porque soy yo la que lo cuenta" (IDEM). Deste modo, percebemos desde as primeiras linhas como o status ou o lugar de fala da narradora é crucial para o entendimento da obra. Ainda que esteja carregada de reflexões sobre a poesia, utopia, e de ares quixotescos, a substância de sua narrativa é a violência, a morte e a destruição.

Uma marca que se manifesta na identidade e no discurso da protagonista de Amuleto é certo tipo de delírio, de insanidade - ela mesma afirma estar louca. A voz de Auxilio é reiterativa, obsessiva, confusa. Porém, percebe-se que o desvario da narradora tem um quê de pitonisa, de 
adivinhação: enquanto "madre de los jóvenes poetas mexicanos", o crime que relata é tão vasto quanto a própria história. E, para ela, a história está intimamente ligada ao terror: "así es la Historia, un cuento corto de terror". (IBIDEM, p. 50). Nesse sentido, no que tange ao terror e à violência, entendemos que Bolaño realiza uma forma de narrativa diferenciada, como afirma Paulo Thomaz:

El autor chileno promueve la experimentación y el artificio, y embiste contra las fórmulas literarias de éxito, construyendo personajes, escenarios, narrativas que tematizan los destructivos y violentos mecanismos de control que enlazan historia, vida y poder. Como crítica radical a la violencia, con el propósito de desarticular el vínculo que enlaza cuerpo y política de una manera destructiva, propone desafíos y preguntas sobre cómo deshacer esos mecanismos de control de lo que es vivo, cómo resistir a ese poder desde las formas literarias residuales que tiene a su disposición (THOMAZ, 2011, p. 111).

Em Amuleto, o relato de Auxilio é uma forma de resistência à violência de Estado. A história de resistência da narradora tece um relato minoritário, marginal, a partir de uma perspectiva que permite explorar os limites convencionais, que nos obriga a pensar o impensável e apresenta um objeto irrepresentável. Em seu livro Histórias locais/projetos globais - colonialidade, saberes subalternos e pensamento liminar, Walter Mignolo faz uma discussão sobre o modo como o imaginário do sistema mundial moderno se configurou pautado no ocidentalismo, apresentando como a evidenciação da diferença colonial pôde favorecer a elevação das vozes subalternas, do pensamento liminar e das histórias locais na contemporaneidade.

\subsubsection{Colonialismo e pensamento liminar}

Mignolo discute os conceitos de colonialidade do poder (e do saber) de Aníbal Quijano e de transmodernidade de Henrique Dussel, conceitos esses que apontam para a diferença colonial como elemento fundamental para se pensar a constituição do sistema moderno/colonial pois, para ele, é impossível pensar a modernidade sem a colonialidade. Essa perspectiva de leitura do imaginário moderno aponta para um processo de descolonização epistêmica, 
pautada em novos locais de enunciação a partir de saberes subalternos, em confronto com os hegemônicos.

Esse processo resulta na forma de pensamento liminar, que opera a partir de diversas histórias locais. Para o autor, o momento atual de crise facilita o surgimento dessa razão subalterna, que vem a partir das margens. Contudo, a autor diferencia sua tese da gnose liminar das teorias críticas pósmodernas, falando de uma relação entre localização geográfica e localização epistemológica, a relação entre o que se teoriza e a partir de onde teoriza.

Em sua proposta de pensar tais relações a partir da América latina, Mignolo se detém no mapeamento de diferentes momentos, processos e ideias que moldaram a imagem das Américas na modernidade, a partir da descolonização no século XIX, e como tais questões se rearticularam no século $X X$, falando do limite e da incapacidade do marxismo em pensar a América latina a partir da diferença colonial, por exemplo.

Minha discussão visa criar, através do pensamento liminar (isto é, pensamento situado entre as ciências humanas e a literatura) um arcabouço no qual a prática literária não seja concebida como objeto de estudo (estético, linguístico ou sociológico), mas como produção de conhecimento teórico; não como "representação" de algo, sociedade ou ideias, mas como reflexão à sua própria moda sobre problemas de interesse humano e histórico (MIGNOLO, 2003, p. 305).

Pensando na América latina enquanto local de produção de teoria, o uruguaio Hugo Achugar trabalha com um conceito que chama de balbucio teórico. Para ele, o mundo contemporâneo se apresenta impotente ante a globalidade e multiplicidade de discursos existentes. Seria esse o momento ideal para a criação de um processo de transformação, diferenciação e crescimento. O balbucio é então um fragmento dessa teoria, uma forma de problematização do establishment.

Trata-se do real e do imaginado, da circunstância e do desejo. É um fragmento, um balbucio. [...] O balbucio é nosso orgulho, nosso capital cultural, nosso discurso raro, nosso discurso queer. $\mathrm{O}$ orgulho daqueles raros que, supostamente, não tem boca como os planetas de Lacan e, portanto, carecem de discurso (ACHUGAR, 2006, p. 14). 
Nesse sentido, Achugar recorre ao conceito de Mignolo de histórias locais. O balbucio teórico estaria ligado à ideia das histórias locais e sua importância para a produção dos discursos teóricos. Trata-se de interesses locais e concretos que estão na base da leitura realizada a partir das margens - ou da periferia. Para Achugar, este tipo de produção não é feita apenas em função da história local, mas também da tomada de posição: "Nesse sentido, um saber que fala de um lugar, mas também acredita, deseja, imagina, constrói, ficcionaliza esse lugar" (IBIDEM, p. 19).

A partir das reflexões de Mignolo e Achugar, podemos pensar Amuleto no contexto das teorias pós-coloniais latino-americanas. Auxilio narra os fatos desde uma margem social e literária que implica mobilidade, nomadismo, resistência ao poder. O relato dessa narradora, que se encontra numa situação extrema, rompe com a temporalidade e apresenta uma série de anacronismos, projetando sua voz desde sua reclusão forçada durante a invasão militar da UNAM, espaço esse que se resume ao banheiro feminino da universidade.

Enquanto narradora, que se desautoriza a todo o momento ao longo do relato, é claro o lugar de fala de Auxilio: uma outsider que deambula pela Cidade do México, revelando visões de um crime que a assombra e do qual foi testemunha - crime que, aliás, jamais será resolvido. O nomadismo é sua condição existencial; estrangeira no México, nem sequer se lembra de quando começou sua viagem pelo país: "Definitivamente, yo creo que llegué en 1965 (pero puede que me equivoque, una casi siempre se equivoca) [...]" (BOLAÑO, 1999, p. 5).

Assim, essa narradora "pouco confiável" desenvolve um relato de caráter testemunhal que se articula principalmente em torno da personagem de Arturo Belano, poeta neovanguardista de Os detetives selvagens, que neste romance também aparece com conotações de protagonista: entre todos os jovens poetas do México, ocupa um lugar especial não só na vida de Auxilio, mas também em vários episódios que compõem o romance.

Nesse sentido, a leitura que realizamos de Amuleto nos faz pensar em um discurso sobre o poder, a memória e a história na América Latina, em que 
os pontos de vista e as estratégias ficcionais figuram não a inteligibilidade do horror ou da ditadura, e sim sua irrepresentabilidade, conforme veremos a seguir.

\subsection{Narrativas do trauma: testemunho e irrepresentabilidade}

A crítica que trata das barbáries contemporâneas tem como onipresente o tema da precariedade da linguagem diante da tarefa de narrar eventos de extrema violência. O filósofo italiano Giorgio Agamben também discute 0 caráter da irrepresentabilidade das experiências-limite: nenhuma língua ou linguagem poderia expressar a experiência extrema das torturas e mortes características de eventos como a Shoah - ou, conforme nos interessa nesta pesquisa, como as ditaduras militares latino-americanas. A morte, enquanto término da existência, não pode ser narrada: o testemunho será o relato de um sobrevivente. Para Agamben, aqui reside a impossibilidade de testemunhar: "tanto a partir de dentro - pois não se pode testemunhar de dentro da morte, não há voz para a extinção da voz - quanto a partir de fora -, pois o outsider é excluído do acontecimento por definição" (AGAMBEN, 2008, p. 44).

Contudo, na intenção de não permitir que o silêncio se transformasse em cúmplice dos torturadores, assassinos e genocidas do século XX, surge nesse contexto a teoria do testemunho, que fala com frequência em uma tentativa de "apresentação", para se diferenciar do efeito de real que já se encontra incorporado no termo "representação".

Em Amuleto, a personagem Auxilio sobrevive e testemunha a invasão da UNAM. Ao longo do texto, percebemos que o relato da personagem conforma certa tentativa de apresentar os fatos ocorridos, a fim de que não sejam de nenhuma maneira esquecidos, apesar de seu testemunho parecer nunca ser levado a sério:

Yo no puedo olvidar nada. Dicen que ése es mi problema. (BOLANO, 1999, p. 128) 
Eso les decía yo a los poetas jóvenes de México (y a Arturito Belano) cuando hablaban mal de José Emilio, pero ellos no me escuchaban o escuchaban sólo la parte anecdótica de la historia, los viajes de Darío y los viajes de Huidobro, las estancias en hospitales, una salud distinta, no condenada a apagarse prematuramente como se apagan tantas cosas en Latinoamérica. (IBIDEM, p. 47)

En el fondo, también se ha de decir, nadie se lo tomaba al pie de la letra. Es decir: la leyenda había partido de mis labios, mis labios ocultos por el dorso de mi mano, y aunque en esencia todo lo que yo había dicho de él cuando él permanecía encerrado en su casa era verdad, por venir de quien venía, de mí, no merecía una credibilidad excesiva. Así son las cosas en este continente. Yo era la madre y me creían, pero tampoco me creían demasiado. (IBIDEM, p. 61)

A necessidade do testemunho surge então como questão de sobrevivência. No prefácio de Se isto es um hombre, Primo Levi, ele mesmo sobrevivente de um campo de concentração, corrobora essa afirmação:

La necesidad de hablar a "los demás", de hacer que "los demás" supiesen, había asumido entre nosotros, antes de nuestra liberación y después de ella, el carácter de un impulso inmediato y violento, hasta el punto de que rivalizaba con nuestras demás necesidades más elementales; este libro lo escribí para satisfacer esta necesidad, en primer lugar, por lo tanto, como una liberación interior. (LEVI, 2002, p. 4)

O irrepresentável jaz na impossibilidade de a experiência ser expressada em uma linguagem convencional; as palavras por si só fracassam na tentativa de narrar o que não suporta uma narrativa. Para narrar o irrepresentável, Levi opta, por exemplo, por uma estética fragmentária: "De aquí su carácter fragmentario: sus capítulos han sido escritos no en una sucesión lógica sino por su orden de urgencia" (IDEM). Também sobre a impossibilidade da escrita do desastre, escreve Blanchot:

No escribir; cuán largo es el camino antes de lograrlo, y nunca es cosa segura, no es una recompensa ni un castigo, hay que escribir solamente en la incertidumbre y la necesidad. No escribir, efecto de escritura; como si fuera un signo de la pasividad, un recurso de la desdicha. (BLANCHOT, op. cit., p.17) 
Bolaño, por meio da narradora de Amuleto, usa como estratégia para dar forma ao indizível as descontinuidades de seu discurso. A irrepresentabilidade do horror, da experiência extrema do século XX, só é acessível através da palavra delirante e metafórica, de imagens como a de Auxilio e o soldado submersos no fundo do lago, ou a visão sinistra da Avenida Guerrero:

[...] la Guerrero, a esa hora, se parece sobre todas las cosas a un cementerio, pero no a un cementerio de 1974, ni a un cementerio de 1968, ni a un cementerio de 1975, sino a un cementerio del año 2666, un cementerio olvidado debajo de un párpado muerto o nonato, las acuosidades desapasionadas de un ojo que por querer olvidar algo ha terminado por olvidarlo todo. (BOLAÑO, op. cit., p. 65)

O testemunho é igualmente uma via de denúncia: apela à verdade e à uma demanda de justiça, funções que se fortalecerão na América Latina dos anos 1990. O relato é um elemento de prova para estabelecer uma verdade a contrapelo da história oficial, conforme afirma Auxilio: "Luego me desperté. Pensé: yo soy el recuerdo" (IBIDEM, p. 130). É a voz dos vencidos que, no entanto, como assinala Idelber Avelar, não incorporou ainda a reflexão sobre a derrota. Ao contrário, retoma o discurso de uma resistência heroica: "não obstante, a recopilação de dados não é ainda a memória da ditadura. A memória da ditadura, no sentido forte da palavra, requer outra linguagem" (AVELAR, 2003, p. 80). Tendo como pano de fundo esse caráter de denúncia do testemunho, analisaremos a seguir como a narrativa ficcional de Bolaño trata da questão da resistência, considerando que nunca se trata de um testemunho totalizante nem de uma denúncia sem seus elementos contraditórios e fragmentários.

\subsection{Amuleto: o canto de uma geração}

Em Amuleto, a violação da autonomia universitária mexicana em 1968 é a coluna vertebral do relato. Para Auxilio, a "mãe de todos os poetas mexicanos", sua permanência no banheiro feminino da Faculdade de Filosofia e Letras da UNAM, ainda que escondida, significa a defesa do que pode ser 
considerado último reduto da autonomia, da liberdade, dentro do contexto político em que se encontra inserida. Desde seu esconderijo, consegue prever, baseada nesse ato violento de repressão, um futuro de morte e sangue que ameaça toda uma geração de jovens.

Os episódios de 18 de setembro de 68 e o massacre de Tlatelolco marcam uma ruptura na história da poesia mexicana e, consequentemente, latino-americana. $O$ discurso ficcional de Bolaño parece deixar entrever que a poesia sempre contém e participa da história de resistência que é, também, a história da revolução. Ao analisarmos as falas de Auxilio, entendemos que trata-se de uma revolução condenada de antemão à derrota e limitada às margens da degradação e do abandono.

Auxilio assinala que, antes de Tlatelolco, os jovens poetas

¡Todos iban creciendo amparados por mi mirada! Es decir: todos iban creciendo en la intemperie mexicana, en la intemperie latinoamericana, que es la intemperie más grande porque es la más escindida y la más desesperada. [...] en las siluetas que nada tenían excepto la utopía de la palabra, una palabra, por otra parte, bastante miserable. ¿Miserable? Sí, admitámoslo, bastante miserable. (BOLAÑO,1999, p. 33)

A narradora reparte com o leitor sua história de resistência individual, mas que, somada às histórias que conta sobre os jovens poetas latinoamericanos, parecem refletir sobre o modo como a resistência se configura na poesia de toda uma geração.

Uma dessas histórias é, por exemplo, o resgate do jovem Ernesto San Epifanio. Confiando na coragem que emanava de lenda de que Arturo Belano teria ido ao Chile comandar uma revolução contra Pinochet (história divulgada por Auxilio), Ernesto decide the pedir ajuda para se livrar de um compromisso com o "rey de los putos" da Avenida Guerrero. E, se durante sua estadia no Chile de Pinochet, Belano não pôde se comportar como herói (simplesmente porque não podia), o fez bravamente no covil do rei, resgatando não só seu amigo como outro rapaz que ali agonizava. Este ar de redentor social apenas se explica pela forte vinculação que se apresenta na obra entre poetas, putos, 
putas, mendigos e afins, como seres pertencentes à margem, companheiros na adversidade.

É interessante pensar na amplitude que ganha esse discurso da narradora que quer se converter, de certa maneira, no canto de uma geração. $\mathrm{Na}$ dedicatória que introduz o texto, Bolaño faz uma homenagem in memoriam a seu amigo Mario Santiago Papasquiaro, que morrera um ano antes da publicação do livro. Os dois formaram juntos, nos idos dos anos 70, um movimento neovanguardista que ficou conhecido como infrarrealismo que trazia a proposta de mudar o mundo e a vida, através da poesia.

Essa dedicatória, juntamente com a reflexão final do romance - a que aborda a história de um crime terrível e do sacrifício de uma geração inteira de jovens latino-americanos, mas também fala do valor e da felicidade desses poetas expressados no canto fantasma -, abrem o texto para uma interpretação coletiva. Ao afirmar que "ese canto es nuestro amuleto" (IBIDEM, p. 138), Auxilio reparte, por meio de sua voz marginalizada, sua história de resistência com toda a América latina.

A violência indiscriminada do Estado transformou essa voz utópica em um grito desarticulado e oculto. A figura de um Arturo Belano que voltava do Chile em 1974 retrata bem esse momento:

Quiero decir: era el mismo de siempre pero en el fondo algo
había cambiado o había crecido o había cambiado y crecido al
mismo tiempo. Quiero decir: la gente, sus amigos, lo
empezaron a mirar como si fuera otro aunque él fuera el mismo
de siempre. Quiero decir: todos esperaban de alguna manera
que él abriera la boca y contara las últimas noticias del Horror,
pero él se mantenía en silencio como si lo que esperaban los
demás se hubiera transmutado en un lenguaje incomprensible
o le importara un carajo. (IBIDEM, pp. 57-58)

\subsubsection{Pós-utopia}

A palavra é a utopia dessa geração que esperava mudar a América Latina, um sonho fadado ao fracasso. A certeza desse destino se dá após o ocorrido em Tlatelolco, quando Auxilio estabelece um elo entre o período pós- 
ditatorial e o surgimento dos novíssimos poetas mexicanos, amigos que fez Arturo Belano após seu retorno, "niños que cuando yo estaba encerrada en la Universidad en septiembre del 68 ni siquiera habían empezado a estudiar la prepa" (IBIDEM, p. 58).

Auxilio, enquanto única expectadora do "parto de la Historia", assistiu o surgimento da geração da resistência. Ela mesma é a mediadora delirante dessa resistência; enclausurada no banheiro feminino, resiste à fome e à solidão, come pedaços de papel higiênico, escreve e destrói:

Así que corté papel higiénico y me puse a escribir. [...] Luego cogí el papel higiénico en donde había escrito y lo arrojé al wáter y tiré de la cadena. El ruido del agua me hizo dar un salto y entonces pensé que estaba perdida [...] Pensé: porque escribí, resistí. Pensé: porque destruí lo escrito me van a descubrir [...] Pensé: ambos hechos están relacionados, escribir y destruir, ocultarse y ser descubierta. (IBIDEM, pp. 130-131).

Os jovens poetas da intempérie contavam com a utopia da palavra; entretanto, esses jovens poetas dos bueiros só podem sussurrar pelos cantos escuros, como faz Arturo Belano quando volta ao México em 1974 após ter visitado o Chile. Em um espaço onde "la muerte es el báculo de Latinoamérica y Latinoamérica no puede caminar sin su báculo." (IBIDEM, p. 56) o único caminho possível é a marginalidade e o desespero. O drama dos jovens poetas mexicanos é a sinédoque do desastre latino-americano reconhecido por Bolaño. Não é a narrativa em si que deixa claros os contornos da história que o autor apresenta; a imagem de Auxilio Lacouture, essa mulher desempregada, sem dentes, louca e derrotada, é a síntese dos efeitos da violência do Estado sobre várias gerações de latino-americanos aprisionados entre a utopia e a triste verdade da história. 


\section{Violência, Chile e exílio em Estrella distante e Nocturno de Chile}

Literatura y exilio son, creo, las dos caras de la misma moneda, nuestro destino puesto en manos del azar.

(Roberto Bolaño, Literatura y exilio)

\subsection{Nocturno de Chile}

No primeiro capítulo desta dissertação, analisamos um romance vital para o entendimento da figuração da violência na obra de Bolaño, cuja história é contada por um narrador exilado: Estrella distante. Neste terceiro capítulo, a fim de discutir questões que relacionam exílio e violência, somaremos ao nosso corpus um romance publicado em 2000.

Nocturno de Chile narra a confissão, durante uma noite febril, de um sacerdote chileno, crítico literário, poeta e membro da Opus Dei que, acreditando encontrar-se à beira da morte, conta sua história de vida, especialmente os anos que vão desde o início da ditadura de Pinochet, com o golpe em 1973, até a chegada da democracia.

Prostrado em uma cama, Sebastián Urrutia Lacroix relata sua vocação religiosa e literária, suas viagens pela Europa e sobretudo suas relações com um velho e influente crítico literário conhecido como Farewell, seu mentor, e com escritores chilenos com quem trabalhou e fez amizades. Lacroix também dramatiza sua relação tensa e intensa com "el joven envejecido", personagem que inventa para representar sua consciência, que o desafia com frequência sobre sua conduta e para o qual faz a sua confissão. Com respeito a isso, Patricia Espinosa, por exemplo, faz uma comparação das práticas do padre Lacroix com as de um ditador, na medida que o crítico:

[...] tiene una misión de servicio a la patria que obviamente deberá poner en ejercicio mediante la práctica de una crítica que opere de acuerdo con la misma lógica de la dictadura: exilio, exclusión, desaparición, mediante la omisión/desvalorización de autores, escrituras, estéticas divergentes al discurso literario. (ESPINOSA, 2006, p. 47) 
É sob essa perspectiva que nos interessa discutir neste capítulo, a partir de Nocturno de Chile, a relação entre exílio e violência. Acreditamos que o exílio funciona como uma produtiva referência da memória da violência do século XX. O exílio, que significa um rompimento com a polis como comunidade, evidencia em sua enunciação a destruição do laço social e converte o exilado em um outsider territorial e político. A existência desse sujeito coloca em crise as categorias fundamentais do Estado-nação, desde a ligação nascimento-nação até o homem-cidadão, que permite abrir o caminho até uma renovação de categorias já improrrogáveis, que questionam a submissão da vida a determinado ordenamento jurídico (biopolítica = política da vida).

As narrativas de Bolaño trazem à tona continuadamente estas questões da transitoriedade dos sujeitos na contemporaneidade, em especial no que tange ao exílio. Em seus livros, como Estrella distante (Belano) e Nocturno de Chile (Lacroix), observamos tanto a melancolia provocada pelo exílio como a estadia límbica do sujeito exílico na transformação de sua experiência. Em romances como estes que analisaremos agora, há claramente uma crítica à política e à cultura do continente americano, transformando o desterro das personagens em oportunidade para viajar, conhecer e denunciar a cumplicidade entre arte e política e entre violência e poder.

Com o propósito de desenvolver este capítulo, formulamos perguntas que nortearão nossas discussões: o que significa o exílio na experiência das personagens nessas duas obras específicas? De que maneira essa expatriação se relaciona com o histórico de violência no Chile? Acreditamos que o deslocamento, o desapego e o desterro são aspectos medulares da história política da sociedade latino-americana. Na tentativa de recuperar a noção de violência expressa nas obras de Bolaño, observamos nos romances o exílio e a conduta que se desprende de uma ética da margem como alternativas à continuidade da violência histórica. 


\subsection{América Latina e Bolaño: marcas de um exílio permanente}

A partir da segunda metade do século XX, em especial nos anos 1970, os países do chamado Cone Sul latino-americano partilharam uma experiência histórica comum: viver sob as ditaduras militares consideradas as mais violentas de todos os tempos. Brasil, Paraguai, Uruguai, Chile e Argentina tiveram seus partidos políticos extintos e a censura instaurada em todos os campos, inclusive o intelectual. Milhares de pessoas foram assassinadas, desaparecidas ou forçadas a se exilar, entre elas vários escritores.

A literatura da época foi, evidentemente, em grande parte influenciada por estes acontecimentos. Entretanto, tratamos aqui a obra de Bolaño não enquanto uma produção específica deste momento de exílio, mas sim como uma narrativa marcada fortemente pelas questões políticas que foram herança de tal período. Consideramos que não só a obra de Bolaño como grande parte das ficções hispano-americanas contemporâneas tem construído um movimento de ressignificação e reestruturação literária, sob a temática da violência, do exílio e de outras relacionadas ao período ditatorial.

\subsubsection{Conceituações do exílio}

Exilar, por definição, é banir da pátria. Mas não apenas da pátria, também das relações afetivas, dos pertencimentos cotidianos, das práticas culturais. Para Giorgio Agamben, o exílio é "o exercício de uma vida nua", que transcende a uma relação jurídico-política marginal, como afirmam Ana Brancher e Fábio Francisco Feltrin de Souza, da UFSC:

Para Giorgio Agamben, pensar a vida é pensar a fronteira da vida e por isso exílio e biopolítica seriam conceitos indissociáveis. O filósofo italiano vai à antiguidade clássica e observa a problemática envolvida na decisão acerca do status jurídico do exílio: é o exercício do direito ou a imposição de uma penalidade? Agamben responde afirmando que o exílio é o exercício da vida nua, a maneira de pertencimento ao estado de exceção. Nesse sentido o exílio não é nem o direito, nem uma punição. O desterro pode ser chamado de bando, antigo termo germânico que designa tanto a exclusão da comunidade, 
quanto o ordenamento do soberano. Para Carl Schmitt, o soberano é aquele que está, ao mesmo tempo, dentro e fora do ordenamento jurídico, pois ele tem o poder de proclamar 0 estado de exceção, de suspender a validade da lei para que ela seja possível, para que se estabeleça o estado de direito. É porque ele pode suspendê-la que pode estabelecê-la. Não podemos saber se o exilado está dentro ou fora da lei, já que ele existe no confim, no limiar, na fronteira da própria vida. Agamben, mostra-nos, pois, que o exílio não é uma relação jurídico-política marginal, o exílio é uma zona neutra de indiferença, entre o externo e o interno, entre exclusão e inclusão. [...] O exílio é um asilo. (BRANCHER e SOUZA, 2008, p. 213).

Este exílio/estar sem lar é então um conceito, e não apenas resultado de uma expatriação física. O estar sem lar representa grande parte da literatura do século XX, incluindo-se a transitoriedade da existência, os relatos de viagem, 0 exílio interior, o não estar em lugar algum nem mesmo na sua própria língua.

Para Edward Said, o exílio é uma fratura incurável entre o ser humano e seu lar. Apesar de a literatura e a história narrarem várias vezes episódios gloriosos decorrentes da condição dos exilados, Said considera tais narrativas apenas um esforço para compensar a "dor mutiladora da separação", pois as realizações do exílio são permanentemente consumidas pela perda de algo deixado para trás para sempre (SAID, 2003).

Said associa o fascínio da literatura pelo exílio à contemporaneidade, uma vez que a moderna cultura ocidental é, em larga medida, obra de exilados, emigrantes, refugiados. O crítico George Steiner chegou a propor a tese de que todo um gênero da literatura ocidental do século $X X$ é "extraterritorial", uma literatura feita por exilados e sobre exilados, símbolo da era do refugiado. $E$ sugeriu que parecia "apropriado que aqueles que criam arte numa civilização de quase barbárie, que produziu tanta gente sem lar, sejam eles mesmos poetas sem casa e errantes entre as línguas. Excêntricos, arredios, nostálgicos, deliberadamente inoportunos..." (STEINER apud SAID, op. cit. 2003, p.46).

Para Said, o exílio não é uma questão de escolha. Outros estudiosos, entretanto, encaram o exílio de uma maneira menos rígida que Said e tentam chamar a atenção para aspectos da vida de um exilado que não estão de 
acordo com a imagem que normalmente se faz dele. Julia Kristeva, por exemplo, afirma o seguinte:

Não pertencer a nenhum lugar, nenhum tempo, nenhum amor. A origem perdida, o enraizamento impossível, a memória imergente, o presente em suspenso. O espaço do estrangeiro é um trem em marcha, um avião em pleno ar, a própria transição que exclui a parada. Pontos de referência, nada mais. O seu tempo? O de uma ressurreição que se lembra da morte e do antes, mas perde a glória do estar além: somente a impressão de um sursis, de ter escapado. (KRISTEVA, 1994, p. 15)

\subsubsection{Exílio em Bolaño}

Tendo em vista estas colocações de Kristeva, reconhecemos nos textos de Bolaño - ainda que à primeira vista a biografia do autor chileno reivindique certo caráter crítico e apátrida - especialmente nos escritos durante seus primeiros anos no exílio, muitas referências a eventos políticos de seu país, que precisamente foram responsáveis por mantê-lo afastado do Chile, e as personagens que viviam nas sombras das atrocidades cometidas durante a ditadura do general Augusto Pinochet.

Devemos assinalar que parte da crítica relaciona a difusão massiva da obra de Bolaño (ABIADA e BERNASOCCHI, 2012) ao fato de sua narrativa dirigir-se marcadamente a um leitor desterritorializado (ou extraterritorial, nas palavras de Steiner) e pós-nacional. Sua "poética de trânsito" encontra eco em milhares de seres humanos que tentam construir sua identidade a partir do mestiço, do híbrido, do interstício:

Sujetos que entienden que la identidad es narrativa, que ponen en evidencia la arbitrariedad de las fronteras y que saben que uno es lo que recuerda, hila y puede decir que es. Inclasificables que quitan peso a palabras monolíticas como Patria y de paso le agregan una suave "s". Lectores que ponen nerviosos a los infatigables fanáticos de lo propio. Individuos concretos que cada vez que se definen y compran el pan ponen en crisis al Estado-nación. Sujetos que tienen como hábito y hábitat el fuera de lugar. (ÁLVAREZ, 2008, p. 77) 
As narrativas de Bolaño, como percebemos em Estrella distante e Nocturno de Chile, apresentariam, portanto, uma tendência a estabelecer uma relação fronteiriça e marginal com o mundo, na medida em que expressam por meio de seus personagens e tramas uma subjetividade movediça, que pode ser interpretada como uma escrita desterritorializada.

Podemos identificar inclusive certa simetria com o próprio escritor que, enquanto figura intelectual exilada, movia-se no que se pode considerar um território marginal ou liminar. No festival literário de Barcelona chamado Kosmópolis, por exemplo, Bolaño fez sua primeira participação, como um completo desconhecido do público; dez anos depois, em 2013, o festival the rendeu homenagem pelos 10 anos de sua morte. Ainda que seu discurso fizesse parte de sua performance como autor, Bolaño afirmava não pertencer a nenhuma nacionalidade (sempre dizia que não se considerava chileno) e declarava sentir-se mais do que confortável fora de qualquer establishment literário. Essa relação fronteiriça e marginal que o indivíduo pode estabelecer com o mundo está marcadamente ficcionalizada em sua produção poética.

... a mí lo mismo me da que digan que soy chileno,

aunque algunos colegas chilenos prefieran verme como

mexicano, o que digan que soy mexicano, aunque

algunos colegas mexicanos prefieran considerarme

español, o, ya de plano, desaparecido en

combate, e incluso lo mismo me da que me

consideren español, aunque algunos colegas

españoles pongan el grito en el cielo y a partir

de ahora digan que soy venezolano, nacido

en Caracas o Bogotá, cosa que tampoco

me disgusta, más bien todo lo contrario.

Lo cierto es que soy chileno y

también soy muchas otras cosas.

(BOLAÑo, 2004, p.38) 
Nesse sentido, nos interessa delinear a relação que as personagens desses dois romances de Bolaño estabelecem com seu país de origem, o Chile. Compreender o exílio como um conceito cultural e como condição histórica do eu político nos permite entender e analisar a condição de certa enunciação da narrativa de Bolaño, apresentada enquanto alteridade, quem sabe um desterro pós-catastrófico relacionado diretamente à representação desse sujeito pós-ditatorial.

$\mathrm{Na}$ narrativa de Bolaño, e mais especialmente em Estrella distante e Nocturno de Chile, o Chile conforma cenários em que tiveram lugar acontecimentos que interferem diretamente na concepção de mundo de uma geração de personagens protagonistas. Há uma série de exilados ideológicos cujos relatos baseiam-se no desamparo e desespero daqueles que reconhecem a derrota de seus projetos utópicos. Assim, a escrita pode ser entendida como uma tentativa de manter viva a memória daqueles anos (e aqui encontramos uma convergência com a teoria de Said) e o fracasso se compreende como a incapacidade da memória de superar a lembrança do horror. Assim, tanto os cenários quanto o tempo em que se desenvolvem as histórias são contados a partir da memória de seus narradores.

No conto Carnet de baile, do livro Putas asesinas, o narrador faz uma descrição do que seria o sujeito político contemporâneo:

Pienso en estos días en que los veteranos de las Brigadas Internacionales visitan España, viejitos que bajan de los autocares con el puño en alto. Fueron 40.000 y hoy vuelven a España 350 o algo así. Pienso en Beltrán Morales, pienso en Rodrigo Lira, pienso en Mario Santiago, pienso en Reinaldo Arenas. Pienso en los poetas muertos en el potro de tortura, en los muertos de sida, de sobredosis, en todos los que creyeron en el paraíso latinoamericano y murieron en el infierno latinoamericano. Pienso en esas obras que acaso permitan a la izquierda salir del foso de la vergüenza y la inoperancia. (BOLAÑO, 2001, pp. 55, 215).

Há aqui uma preocupação clara em construir personagens altamente instáveis e feridas, cujas histórias estão repletas de desaparecimentos e de violência, de modo que só sobrem restos e fragmentos de suas trajetórias políticas. Para construir precisamente essas personagens, o narrador dos 
textos de Bolaño necessita trazer para os relatos igualmente a formação histórica desses indivíduos.

O que vemos, então, é a presença de elementos ficcionais vinculados ao romance de formação. O Bildungsroman é usado como uma estratégia narrativa para expor a biografia dos personagens, sua infância, juventude e idade adulta, enfatizando as aventuras dessas personagens no curso de sua vida. O marco cultural que define as biografias desses sujeitos é o aprendizado da violência política; a maioria das personagens, como em Estrella distante e Los detectives salvajes, por exemplo, pertencem ao mundo latino-americano dos anos 60 e 70. Isto pressupõe um significativo contato com o ambiente ideológico das novas esquerdas e seu enfrentamento com as ditaduras que emergiram nesses países.

Sendo assim, entre o corpus literário que Bolaño produziu em carreira, podemos destacar esse grupo de romances, entre os quais se destacam Estrella distante e Nocturno de Chile, que constituem um ciclo narrativo dedicado ao Chile e aos anos da ditadura. Essas narrativas, que de alguma maneira fazem referência a aspectos da matéria biográfica do autor, evocam indivíduos cuja vida se desenrola nas periferias, à margem das decisões importantes, a partir da memória marcada pelo horror.

\subsection{Exílio e horror em Estrella distante}

Segundo Patricia Espinosa, a visão do Chile durante a ditadura que se constitui na narrativa de Bolaño está sempre dada a partir de personagens que se localizam à margem da metrópole, a fim de representar o conflito existente entre centro e periferia. É o retrato do choque entre a macro realidade do centro e a micro realidade da vida dos protagonistas (ESPINOSA, 2006).

Essas personagens são testemunhas do conflito entre a realidade hostil e a própria impotência diante da situação; nestes cenários, se configura um discurso de marginalidade e desenraizamento ou des-pertencimento do sujeito, como observamos, por exemplo, na personagem Diego Soto em Estrella 
distante, quem "aparecía y desaparecía como un fantasma en todos los lugares donde había pelea, en todos los lugares em donde los latinoamericanos, desesperados, generosos, enloquecidos, valientes, aborrecibles, destruían y volvían a destruir la realidad en um intento último abocado al fracaso" (BOLAÑO, 1996, p. 66).

O Chile passa a conformar então um território hostil em Estrella distante. O narrador, Arturo B., reflete que "en la América Latina de los setenta, sólo era eso, una vida triste, llena de pequeñas mezquindades, algunas hechas sin ni siquiera mala intención" (IBIDEM, p. 68). Neste ambiente em que a frustração supera ainda a utopia desaparecida e a derrota de ideais, Carlos Wieder, também conhecido como Alberto Ruiz-Tagle (sobrenome real do presidente do Chile à época da escrita do romance), se apresenta como um anti-herói da ditadura de Pinochet, cujos atos de sadismo representam a demência convertida em obra de arte. Diante do espetáculo artístico de Wieder, Arturo B. nos dá pistas do sentimento que imperava em tempos de ditadura: "Hasta ese momento nunca había visto tanta tristeza junta" (IBIDEM, p. 39). Também representa, a partir do grito desesperado de uma das personagens, 0 testemunho de uma nação: "sólo somos chilenos, señor, dijo, inocentes, inocentes" (IBIDEM, p. 37).

De fato, como assinalamos anteriormente, tristeza e dor são colocados como sentimentos amplamente presentes na sociedade chilena durante os anos do regime militar. Este sentimento encontra-se também na mesma personagem, que passa a ser retratada como uma vítima do momento histórico; assim entende, a partir de sua perspectiva de membro da repressão, o policial que o acompanhava em algumas missões:

El teniente de la Fuerza Aérea sólo hizo lo que todos los chilenos tuvieron que hacer o quisieron y no pudieron hacer. En las guerras internas los prisioneros son un estorbo [...] y ¿Quién en el medio del terremoto de la historia, podía culparlo de haberse excedido en el cumplimiento del deber? (IBIDEM, p. 118)

A história de Wieder parece então ligada ao destino dos chilenos. Como ele, as personagens imersas na ditadura assistem a conversão da violência em 
um espetáculo cotidiano e a realidade se transforma em algo monstruoso: "me parece que estamos entrando en el campeonato mundial de la fealdad y la brutalidad" (IBIDEM, p. 27).

No entanto, Celina Manzoni assinala a ausência de uma intenção de denúncia no romance, pois em lugar de sentimentos de indignação e raiva, a narrativa é construída a partir da frieza e resignação de quem está consciente de que já não há mais espaço para mudanças: é o discurso da derrota, onde identificamos mais uma vez esse exílio ideológico da narrativa de Bolaño (MANZONI, 2006).

Há igualmente uma possibilidade de leitura do romance, a partir da ótica do exílio, no significado do nome Wieder: "Wieder, según Bibiano nos contó, quería decir otra vez, de nuevo, nuevamente, por segunda vez, de vuelta, en algunos contextos una y otra vez, la próxima vez en frases que apuntan al futuro" (BOLAÑO, op. cit., p. 50). No campo semântico da palavra, como nos apresenta o narrador, se esconde a alusão estética de um poeta relacionado com o mal, precisamente a monstruosidade política que impera no Chile que deixaram. Wieder é então a referência à volta do horror.

Nesse sentido, cabe destacar que no decorrer do romance, o "voltar", a "segunda vez", o "retorno", são reiterados de diferentes maneiras. O narrador, já na última parte do romance, quer apenas saber o paradeiro de Wieder quando inicia sua investigação com o detetive Romero. Então reencontra a personagem Amalia Maluenda, a mulher mapuche que foi testemunha do primeiro e grande assassinato de Wieder, o das irmãs Garmendia, que aparece como a conexão com o discurso do narrador: "La noche del crimen, en su memoria, se ha fundido a una larga historia de homicidios e injusticias" (IBIDEM, p. 119). Aqui se confundem, na memória de Maluenda, a história do testemunho do assassinato das irmãs poetisas com a própria história do terror no Chile ditatorial.

Essa certeza de memória leva o narrador continuadamente a um deslocamento narrativo: de lugar em lugar, de relato em relato, ele vai juntando as peças que juntas formarão um esboço do que aconteceu. Deslocar-se parece ser a única maneira de evitar e escapar da reiteração dos 
acontecimentos. Assim, não resulta estranho que o exílio se transforme em um caminho, em um destino para a maioria das personagens significativas da narrativa.

\subsection{Exílio em Nocturno de Chile: nova perspectiva}

Se o horror dos anos da ditadura é narrado em Estrella distante do ponto de vista dos chilenos, a ditadura será apresentada também do ponto de vista dos detentores do poder, agora em Nocturno de Chile. A partir de seu leito de morte, tomamos conhecimento das reflexões já antigas do sacerdote da Opus Dei Sebastián Urrutia Lacroix.

Sobre essa questão, Gonzalo Aguilar, por exemplo, afirma que Sebastián Lacroix encarna a figura principal de um relato sobre os equívocos do amor à pátria (AGUILAR, 2002). Nele se faz presente o sentimento de melancolia mais profundo. Ao fim de sua vida, o sacerdote rememora os anos em que atuou a serviço da ditadura de Augusto Pinochet, inclusive chegando a dar-lhe aulas de marxismo. E, ainda, relata como foi testemunha de torturas que aconteciam na mesma casa onde se realizavam reuniões literárias. Já em seus últimos dias de vida, o padre se sente uma vítima de um pesadelo que lhe parece muito real.

Se Estrella distante oferece um mundo em que a literatura e o terror caminham de mãos dadas, Nocturno de Chile retoma essa direção, de certo modo, ao nos apresentar precisamente a casa de María Canales, lugar onde se realizam reuniões literárias ao mesmo tempo em que seu marido, Jimmy Thomson, praticava a tortura em presos políticos do regime. Por outro lado, também nos apresenta os retratos, ainda que fugazes, das principais figuras do regime chileno, nos quais encarna a evidência do fracasso literário no Chile daqueles anos.

À margem da precária situação literária retratada, fora do ambiente próximo ao poder, o mundo exterior se apresenta como um lugar decadente e totalmente oposto a esse onde vive o sacerdote, que encara esse exterior com 
medo e asco: "[...] todos eran feos. Las campesinas eran feas y sus palabras incoherentes. El campesino quieto era feo y su inmovilidad incoherente. Los campesinos eran feos y su singladura en zigzag incoherente" (BOLAÑO, 2009, p. 20). Assim, o retrato do Chile de seu tempo que oferece Lacroix é de gente "feia" e "incoerente" diante daqueles que permaneceram próximos ou alheios à situação.

Essa descrição do Chile daquela época se estende ao resto da América hispânica com o quadro de um pintor guatemalteco intitulado Paisaje de Ciudad de México uma hora antes del amanecer. Nele se diz que não se percebiam figuras humanas, e sim esqueletos esfumados que podiam ser tanto de pessoas como de animais. Essa imagem está presente no leito de morte do padre Lacroix, quando ele, num delírio, vê um grupo de jovens que cruzam um vale e caem num abismo que representa o futuro das novas gerações hispanoamericanas (a mesma imagem está presente no final de Amuleto).

Sendo assim, podemos dizer que os cenários nestas narrativas acabam por configurar certo sentimento apocalíptico unitário, cuja origem termina no fracasso que impôs ao continente o aparecimento de regimes totalitários e crimes inexplicáveis. As personagens, sejam exiladas ou residentes na América hispânica, seguem seus caminhos errantes como párias rumo a este abismo em que se converteu a pátria para seus habitantes. Todos são portadores de um trauma desatado por acontecimentos terríveis que marcaram suas vidas e, irremediavelmente, os ligou à miséria.

De acordo com Ignacio Echevarría, "por la obra de Bolaño transitan errantes, fantasmales - los náufragos de un continente en el que el exilio es la figura épica de la desolación y la vastedad" (ECHEVARRÍA, 2002, p. 193). Essa condição da pátria como território hostil é um dos grandes traços que caracteriza o anti-herói bolaniano. Os países que encontramos ao largo de sua obra são sempre terrenos áridos onde o ser humano agoniza e a única salvação para o terror estará em fugir, exilar-se, já que a busca pela utopia já não é possível. Esse balanço final o faz o próprio Bolaño, quando da recepção do prêmio Rómulo Gallegos: 
Y esto me viene a la cabeza porque en gran medida todo lo que he escrito es una carta de amor o de despedida a mi propia generación, los que nacimos en la década del cincuenta y los que escogimos en un momento dado el ejercicio de la milicia, en este caso sería más correcto decir la militancia, y entregamos lo poco que teníamos, lo mucho que teníamos, que era nuestra juventud, a una causa que creímos la más generosa de las causas del mundo y que en cierta forma lo era, pero que en la realidad no lo era. De más está decir que luchamos a brazo partido, pero tuvimos jefes corruptos, líderes cobardes, un aparato de propaganda que era peor que una leprosería, luchamos por partidos que de haber vencido nos habrían enviado de inmediato a un campo de trabajos forzados, luchamos y pusimos toda nuestra generosidad en un ideal que hacía más de cincuenta años que estaba muerto, y algunos lo sabíamos, y cómo no lo íbamos a saber si habíamos leído a Trotski o éramos trotskistas, pero igual lo hicimos, porque fuimos estúpidos y generosos, como son los jóvenes, que todo lo entregan y no piden nada en cambio, y ahora de esos jóvenes ya no queda nada, los que no murieron en Bolivia, murieron en Argentina o en Perú, y los que sobrevivieron se fueron a morir a Chile o a México, y a los que no mataron allí los mataron después en Nicaragua, en Colombia, en el Salvador. Toda Latinoamérica está sembrada con los huesos de estos jóvenes olvidados. (BOLAÑO, 2004) 


\section{5. Últimas considerações}

A representação ficcional do mal faz alusão a uma experiência e a um discurso. Entrecruzam-se nesse âmbito relatos, imagens e subjetividades. Como imaginário literário, o mal tem sido elaborado e reelaborado a partir de variados eventos, como as guerras e os estados de exceção, onde a prática contínua do horror cria territórios que, com o tempo, banalizam o próprio horror.

Sendo assim, a experiência e o discurso do horror permitem uma aproximação a uma zona específica situada dentro da obra ficcional de Bolaño, articulados mediante um registro de episódios relacionados com o crime, as situações limite e a violência. Apesar de termos concentrado nossa pesquisa em torno de apenas três romances do autor, consideramos que todo o extenso corpus literário de Bolaño, incluindo poesias, críticas e ensaios, parecem não só partir de um mesmo ponto de ação, como também convergir para um mesmo ponto de chegada, quem sabe condensado, em parte, em seu manifesto infrarrealista: a poesia enquanto resistência à violência.

O infrarrealismo é um movimento poético fundado em 1975 por Bolaño e seu amigo Mario Santiago Papasquiaro. O movimento se caracteriza pela busca de uma poesia livre e pessoal, que representasse a postura de seus membros diante da vida, às margens das convenções sociais.

É importante destacarmos aqui o contexto histórico em que o movimento surgiu. Em 1968, aos 15 anos, Bolaño chegava com seus pais ao México; nesse mesmo ano, era conduzida no país a Guerra sucia, conjunto de medidas de repressão militar e política destinadas a dissolver os movimentos de oposição política e armada contra o Estado mexicano. Uma das principais consequências dessa guerra foi a sanguinária repressão militar ao movimento estudantil de 1968, episódio em que a UNAM foi invadida e ficou conhecido como Masacre de Tlatelolco. Algum tempo depois, Bolaño regressa ao Chile com o propósito de apoiar o governo de Salvador Allende e da Unidad Popular; após o golpe de Estado que deu início ao regime militar de Pinochet, Bolaño 
volta ao México, onde conhece Papasquiaro. Desde então iniciaram uma estreita e longa amizade, que deu origem ao movimento infrarrealista.

A década de 70 representa em Bolaño um momento de extraordinário fluxo narrativo-poético. Em seus primeiros livros, emerge uma lírica inserida na cotidianidade de sujeito extremamente solitário, porém capaz de conter uma visão política dirigida ao coletivo latino-americano e focada em constatar a ruína, a perda, o fracasso de um projeto revolucionário e o triunfo de um Estado ditatorial. Trata-se de um período poético no qual ele parece dialogar com a história chilena a partir da tristeza, do medo, mas também com alguma esperança de que tudo volte a se rearticular.

Desde seus primeiros manuscritos, percebemos que a matéria biográfica se cruza com a literatura, centralizada na figura do poeta que mantém "los ojos abiertos", o símbolo maior da resistência, que conjuga arte e vida, a fim de reestabelecer a tensão revolucionária entre o artista e a sociedade, assim como uma personagem fala sobre os poetas em Los detectives salvajes:

Y una noche, poco antes del año nuevo de 1976, poco antes
de que se marcharan a Sonora, comprendí que era su manera
de hacer política. Una manera que yo ya no comparto y que
entonces no entendía, que no sé si era buena o mala, correcta
o equivocada, pero que era su manera de hacer política, de
incidir políticamente en la realidad. (BOLAÑO, 1998, p. 340)

A poética bolaniana considera a literatura como um território de resistência, a partir da consciência de um sujeito dizimado pela história, mas, apesar de tudo, disposto a sobreviver em busca de uma utopia que the dá espanto. Todavia, Bolaño não deixa de reparar nos perigos da arte de vanguarda e o discurso sobre arte ligado ao fascismo (como vemos em Estrella distante), sempre cultivando uma disciplina da suspeição.

A obra de arte em Bolaño se desliga da autonomia e se instala em um permanente diálogo com a história, a política, a cultura, a própria arte enquanto instituição. Sua escrita a partir da margem sustenta o conceito de resistência, em um hibridismo de literatura e identidade periférica, mediante discursos contra culturais e subversivos, apesar do forte processo de institucionalização 
pelo qual passou o autor e sua obra após sua morte, que acabou por suavizar e mitificar sua figura, conforme vemos na crítica que Alan Pauls escreveu sobre a exposição do arquivo do chileno em Barcelona:

\begin{abstract}
Pero la gravedad sacramental de la puesta en escena de la muestra no contradecía sólo ese entusiasta imaginario yonqui basado en una confusión de yoes sino también el nuestro, el de los pares latinoamericanos del escritor -más sensibles, en teoría, a la dimensión farsesca de la primera persona que a sus ínfulas de autenticidad, y más seducidos por su ubicuidad internacional que por su exotismo-, en el que Bolaño seguía y sigue reinando a la vez como el general y el soldado raso, el gurú y el groupie cachorro, el ideólogo y el militante modelo de un programa de bohemia, vitalismo y velocidad que no nos interpelaba tanto desde el Cortázar de Rayuela (al que la literatura de Bolaño, por otra parte, hizo y hace mucho porque volvamos). (PAULS, 2013)
\end{abstract}

Um sem número de escritores do Cone Sul citados na obra de Bolaño nos dão conta de um projeto onde predominam o desmantelamento e a hibridização de gêneros e da figuração/representação da realidade, um cruzamento de linhas narrativas que vão tecendo uma rede que elimina os centros, fragmentando a noção de totalidade.

O horror e a violência presente no território latino-americano, um espaço quase impossível de resplandecer esperança, parece encontrar alguma resistência apenas quando se enfrenta com um poeta, como o Belano de Estrella distante ou a Auxilio de Amuleto, sujeitos detentores da memória, que vivem o desapego sem nostalgia, na intenção de sobreviver, conscientes de sua condição de subalternos.

Para Bolaño, a América Latina será sempre um território marcado pela ditadura, pelo fascismo, pela naturalização do crime, pela banalização do mal, pela acumulação de cadáveres, pelos desaparecimentos, pelo medo em todas as suas formas, ou seja, pela violência em todas as suas formas. É por este território que os poetas perambulam, ainda que saibam que podem cair no abismo a qualquer momento.

O século $X X$ se cansou de ensaiar variações da ideia hegeliana de morte da arte e morte da literatura para dar origem a uma época de toda a 
humanidade onde mais se escreve e mais se lê, e não apenas livros. Parece no mínimo irônico que a narrativa latino-americana abra o século XXI destacando um autor que afirma desejar a morte da literatura e que se enfrente sem esperança a inércia da vitalidade da mesma. Isso não quer dizer que Bolaño esteja pedindo, desde os obscuros rincões de suas obras, que a literatura termine de uma vez e para sempre. A radicalidade de Bolaño está em sua proposta de uma imagem da literatura que que é impossível de conciliar com sua prática e que deve ir além da própria literatura. De Bolaño podemos dizer que nos oferece uma estrutura do mundo e das relações sociais que geram esse corpo literário, do qual os debates que consignamos aqui são apenas uma parte. 


\section{Referências}

\section{Bibliografia citada:}

ABIADA, José Manuel López de. BERNASOCCHI, Augusta López (Ed.). Roberto Bolaño. Estrella cercana. Ensayos sobre su obra. Madrid: Editorial Verbum, 2012.

ACHUGAR, Hugo. Planetas sem boca: escritos efêmeros sobre arte, cultura e literatura. Belo Horizonte: Editora UFMG, 2006.

AGAMBEN, Giorgio. Estado de exceção. São Paulo: Boitempo, 2004. . Homo sacer: o poder soberano e a vida nua. Belo Horizonte: Editora UFMG, 2002. . O que resta de Auschwitz. São Paulo: Boitempo, 2008.

AGUILAR, Gonzalo. Los amuletos salvajes de un novelista. Un recorrido por la obra de Roberto Bolaño. 2001. Disponível em < http://old.clarin.com/suplementos/cultura/2001/03/25/u-00411.htm>, acesso em 20/08/2015.

ÁLVAREZ, Enrique Díaz. Bolaño y el fuera de lugar. Revista de la Universidad de México, ํㅡ 54, 2008.

ANDERS, Gunther. Nosotros, los hijos de Eichamnn. Carta abierta a Klaus Eichmann. Barcelona: Ediciones Paidós Ibérica, 2001.

ARENDT, Hannah. A condição humana. Rio de Janeiro: Forense Universitária, 2004.

AVELAR, Idelber. Alegorias da derrota. A ficção pós-ditatorial e o trabalho do luto na América Latina. Belo Horizonte: Editora UFMG, 2003.

BADIOU, Alain. O século. São Paulo: Ideias \& Letras, 2007.

BAUMAN, Z. Amor líquido. Sobre a fragilidade dos laços humanos. Rio de Janeiro: Jorge Zahar, 2004. 
BENJAMIM, Walter. Magia e técnica, arte e política: ensaios sobre literatura e história da cultura. Tradução de Sérgio Paulo Rouanet. São Paulo: Brasiliense, 1994.

BOLAÑO, Roberto. Amuleto. Barcelona: Anagrama, 1999.

- Entre paréntesis: ensayos, artículos y discursos. Barcelona: Anagrama, 2004.

. Estrella distante. Barcelona: Anagrama, 1996.

. La literatura nazi en América. Barcelona: Anagrama, 2010.

. La Universidad desconocida. Barcelona: Anagrama, 2007.

. Los detectives salvajes. Barcelona: Anagrama, 2008.

. Nocturno de Chile. Barcelona: Anagrama, 2009.

. Primer Manifiesto Infrarrealista. México, 2976.

. Putas asesinas. Barcelona: Anagrama, 2001.

BOLOGNESE, Chiara. Roberto Bolaño y Raúl Zurita: Referencias Cruzadas. Anales de la literatura chilena. Barcelona: Universidad Autónoma de Barcelona, 2010.

BRAITHWAITE, Andrés. Bolaño por sí mismo. Entrevistas escogidas. Santiago: Ediciones Universidad Diego Portales, 2011.

BRANCHER, Ana. SOUZA, Fábio Francisco Feltrin de. Políticas na exterioridade - Notas sobre o exílio dos escritores latinoamericanos. Revista Esboços, ํㅜ 20, 2008, UFSC.

CCBB - Centre de Cultura Contemporània de Barcelona. Archivo Bolaño: 1977-2003. Barcelona: Diputació Barcelona, 2013.

COELHO, Teixeira. História natural da ditadura. São Paulo: lluminuras, 2006.

DUARTE, André de Macedo. De Michel Foucault a Giorgio Agamben: a trajetória do conceito de biopolítica. In: Fenomenologia Hoje III - Bioética, 
biotecnologia, biopolítica. Ed. Ricardo Timm de Souza; Nythamar Fernandes de Oliveira. Porto Alegre: Editora da PUCRS, 2008.

DORFMAN, Ariel. Imaginación y violencia en América. 2. ㄹ ed. Barcelona: 1972. ESPINOSA, Patricia. Crítica y autoritarismo en Nocturno de Chile de Roberto Bolaño. In: Fernando Moreno (Coord.). La memoria de la dictadura: Nocturno de Chile. Paris: Ellipses Édition, 2006, pp. 41-48.

ESPOSITO, Roberto. Bíos. Buenos Aires: Amorrortu Editores, 2006.

FOUCAULT, M. Em defesa da sociedade. Curso no Collège de France (19751976). São Paulo: Martins Fontes, 2005.

. História da Sexualidade, vol. I A vontade de saber. Rio de Janeiro: Edições Graal, 1988.

KRISTEVA, Julia. Tocata e fuga para o estrangeiro. In: Estrangeiros para nós mesmos. Tradução: Maria Carlota Carvalho Gomes. Rio de Janeiro: Rocco, 1994, pp. 9-46.

LEVI, Primo. Se isto es um hombre. Barcelona: Muchnik Editores, 2002.

LÓPEZ-VICUÑA, Ignacio. Malestar en la literatura: escritura y barbarie en Estrella distante y Nocturno do Chile de Roberto Bolaño. Revista Chilena de Literatura, novembro/2009, número 75, p. 199-215.

LUIZ, José Victor Regadas. Estado de exceção como regra: o impasse contemporâneo à resistência política no pensamento de Giorgio Agamben. Disponível em <www.estig.ipbeja.pt/ ac_direito/jose_luiz_33.pdf>, acesso em 10/03/2015.

MANZONI, Celina. Roberto Bolaño: la escritura como tauromaquia. Buenos Aires: Corregidor, 2006.

MIGNOLO, Walter. Histórias locais / projetos globais: colonialidade, saberes subalternos e pensamento liminar. Belo Horizonte: Editora UFMG, 2003.

MORALES, Rodrigo Ramírez. Memoria, intemperie y sobrevivencia en Amuleto (Informe final de seminario de grado para optar al grado de licenciado en 
Lengua y Literatura Hispánica con mención en Literatura). Universidad de Chile, 2007. Disponível em <http://repositorio.uchile.cl/handle/2250/110422>. Acesso em 01/11/2015.

PAULS, Alan. Qué hacer. Página 12: Radar, 2013. Disponível em $<$ http://www.pagina12.com.ar/diario/suplementos/radar/subnotas/9048-20202013-08-11.html>. Acesso em 01/11/2015.

PELBART, P.P. Vida nua, vida besta, uma vida. In: Revista Trópico, p.1-5, 2007. Disponível em <http://p.php.uol.com.br/tropico/html/textos/2792,1.shl>. Acesso em 26/03/2015.

PENNA, João Camillo. Estado de exceção: um novo paradigma da política? In: Estudos de Literatura Brasileira Contemporânea, nº. 29. Brasília, janeiro-junho de 2007, pp. 179-204.

RAMA, Ángel. La novela latinoamericana 1920-1980. Bogotá: Procultura, 1982.

ROSA, Susel Oliveira da. A banalização da violência no contexto biopolítico do Estado de exceção. In: Revista MÉTIS: história \& cultura - v. 5, n. 10, p. 217234, jul./dez. 2006.2 Disponível em <http://www.ucs.br/etc/revistas/index.php/metis/>. Acesso em 26/03/2015.

SAID, Edward W. Reflexões sobre o exílio. In: Reflexões sobre o exílio e outros ensaios. Tradução: Pedro Maia Soares. São Paulo: Companhia das Letras, 2003, pp. 46-60.

SALGADO, Carlos Vargas. ¿La escritura del mal, o el mal de la escritura? Estrella distante de Roberto Bolaño. Espéculo. Revista de estudios literarios. Universidad Complutense de Madrid, 2011.

SÁNCHEZ, Ana María Amar. Espacio y representación. La construcción de América Latina. In: Boletín 5. Rosario, Outubro, 1996, p. 1-16.

SHAW, Donald L. The post-boom in spanish american ficction. Nova lorque: State University of New York Press, 1998.

SOLDÁN, Edmundo Paz. PATRIAU, Gustavo Faverón. Bolaño salvaje. Barcelona: Editorial Candaya, 2008. 
SOLDÁN, Edmundo Paz. Entre la tradición y la innovación: globalismos locales y realidades virtuales en la nueva narrativa latinoamericana. In: Becerra, Eduardo (comp.). Desafíos de la ficción. Murcia: Cuadernos de América sin nombre, 2002, pp. 57-66.

THOMAZ, Paulo. Las desavenencias con lo literario: Amuleto de Roberto Bolaño. In: Revista Contextos, n. 25, p. 109-116, 2011. Disponível em < http://www.umce.cl/joomlatools-files/docman files/universidad/revistas/contextos/n25-07.pdf>. Acesso em 26/03/2015.

VOLPI, Jorge. El insomnio de Bolívar. Madrid: Debate, 2009.

- Breve guía de la narrativa hispánica de América a principios del siglo XXI (en más de 100 aforismos, casi tuits). Blog de Jorge Volpi, publicado em 05/09/2011. Disponível em <http://www.elboomeran.com/blogpost/12/11221/jorge-volpi/breve-guia-de-lanarrativa- hispanica-de-america-aprincipios-del-siglo-xxi-en-mas-de-100-aforismos-casi-tuits/>. Acesso em 01/11/2015.

\section{Bibliografia consultada:}

ADORNO, T. W. \& HORKHEIMER, M. Dialética do esclarecimento: fragmentos filosóficos. Trad. Guido Antonio de Almeida. Rio de Janeiro: Jorge Zahar Ed., 1985.

BARTHES, Roland. Aula: aula inaugural da cadeira de semiologia literária do Colégio de França, pronunciada dia 7 de janeiro de 1977/ Roland Barthes; tradução e posfácio de Leyla Perrone-Moisés. São Paulo: Cultrix, 2007.

CANDIDO, Antônio. Literatura e sociedade: estudos de teoria e história literária. 8ae ed. São Paulo: T. A Queiroz, 2000.

CORNEJO POLAR, A. O condor voa. Belo Horizonte: UFMG, 2000.

DALCASTAGNÈ, Regina \& THOMAZ Paulo C. (orgs.) Pelas margens: representação na narrativa brasileira contemporânea. Vinhedo: Editora Horizonte, 2011. 
DERRIDA, Jacques. A escritura e a diferença. São Paulo: Perspectiva, 1995.

GILMAN, Claudia. Entre la pluma y el fusil. Buenos Aires: Siglo XXI, 2003.

GINZBURG, Carlo. Mitos, emblemas e sinais. São Paulo: Companhia das Letras, 1998.

GIORGI, Gabriel. RODRÍGUEZ, Fermin (comps.). Ensayos sobre biopolítica: excesos de vida. Buenos Aires: Paidós, 2007, p. 187-215.

GONZALEZ ECHEVARRIA, Roberto (comp.). Historia y ficción en la narrativa hispanoamericana. Coloquio de Yale. Venezuela, Monte Ávila: 1984.

LATOUR, Bruno. Jamais fomos modernos. Rio de Janeiro: 34 Literatura S/C Ltda, 1994.

LUDMER, Josefina. Literaturas postautónomas 2.0. Disponível em $<$ http://www.lehman.edu/faculty/guinazu/ciberletras/v17/ludmer.htm. Acesso em 27/08/2012/> . Acesso em 01/11/2015.

MARRAS, Sergio. El héroe improbable (Cómo Arturo Belano sempre quiso ser Benno von Archimboldi). Santiago: RIL Editores, 2011.

OLMOS, Ana Cecilia. Transgredir o gênero: políticas da escritura na literatura hispano-americana atual. Revista Estudos de literatura brasileira contemporânea, n.38, jul./dez. 2011, p.11-21.

RESENDE, Beatriz (org). A literatura latino- americana do século XXI. Rio de Janeiro, Aeroplano, 2005.

SARLO, Beatriz. Tiempo pasado: cultura de la memoria y primera persona. Buenos Aires: Siglo XXI Editores Argentinos, 2005. 